Atmos. Chem. Phys., 20, 15937-15967, 2020

https://doi.org/10.5194/acp-20-15937-2020

(C) Author(s) 2020. This work is distributed under

the Creative Commons Attribution 4.0 License.

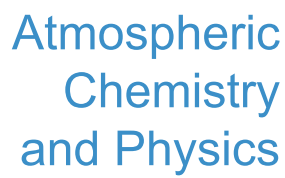

(c) (P)

\title{
Pan-Arctic surface ozone: modelling vs. measurements
}

\author{
Xin Yang ${ }^{1}$, Anne-M. Blechschmidt ${ }^{2}$, Kristof Bognar ${ }^{3}$, Audra McClure-Begley ${ }^{4,5}$, Sara Morris ${ }^{4,5}$, \\ Irina Petropavlovskikh ${ }^{4,5}$, Andreas Richter ${ }^{2}$, Henrik Skov ${ }^{6}$, Kimberly Strong ${ }^{3}$, David W. Tarasick ${ }^{7}$, Taneil Uttal ${ }^{5}$, \\ Mika Vestenius $^{8}$, and Xiaoyi Zhao ${ }^{7}$ \\ ${ }^{1}$ British Antarctic Survey, UK Research Innovation, Cambridge, UK \\ ${ }^{2}$ Institute of Environmental Physics, University of Bremen, Bremen, Germany \\ ${ }^{3}$ Department of Physics, University of Toronto, Toronto, ON, Canada \\ ${ }^{4}$ Cooperative Institute for Research in Environmental Sciences, University of Colorado, Boulder, CO, USA \\ ${ }^{5}$ NOAA Earth System Research Laboratory, Boulder, CO, USA \\ ${ }^{6}$ iClimate, Department of Environmental Science, Aarhus University, Denmark \\ ${ }^{7}$ Air Quality Research Division, Environment and Climate Change Canada, Toronto, ON, Canada \\ ${ }^{8}$ Atmopsheric Composition Research, Finnish Meteorological Institute, Helsinki, Finland
}

Correspondence: Xin Yang (xinyang55@bas.ac.uk)

Received: 28 October 2019 - Discussion started: 26 February 2020

Revised: 23 September 2020 - Accepted: 19 October 2020 - Published: 21 December 2020

\begin{abstract}
Within the framework of the International Arctic Systems for Observing the Atmosphere (IASOA), we report a modelling-based study on surface ozone across the Arctic. We use surface ozone from six sites - Summit (Greenland), Pallas (Finland), Barrow (USA), Alert (Canada), Tiksi (Russia), and Villum Research Station (VRS) at Station Nord (North Greenland, Danish realm) - and ozone-sonde data from three Canadian sites: Resolute, Eureka, and Alert. Two global chemistry models - a global chemistry transport model (parallelised-Tropospheric Offline Model of Chemistry and Transport, p-TOMCAT) and a global chemistry climate model (United Kingdom Chemistry and Aerosol, UKCA) - are used for model data comparisons. Remotely sensed data of $\mathrm{BrO}$ from the GOME-2 satellite instrument and ground-based multi-axis differential optical absorption spectroscopy (MAX-DOAS) at Eureka, Canada, are used for model validation.

The observed climatology data show that spring surface ozone at coastal sites is heavily depleted, making ozone seasonality at Arctic coastal sites distinctly different from that at inland sites. Model simulations show that surface ozone can be greatly reduced by bromine chemistry. In April, bromine chemistry can cause a net ozone loss (monthly mean) of 10-20 ppbv, with almost half attributable to open-oceansourced bromine and the rest to sea-ice-sourced bromine. However, the open-ocean-sourced bromine, via sea spray
\end{abstract}

bromide depletion, cannot by itself produce ozone depletion events (ODEs; defined as ozone volume mixing ratios, VMRs, $<10$ ppbv). In contrast, sea-ice-sourced bromine, via sea salt aerosol (SSA) production from blowing snow, can produce ODEs even without bromine from sea spray, highlighting the importance of sea ice surface in polar boundary layer chemistry.

Modelled total inorganic bromine $\left(\mathrm{Br}_{Y}\right)$ over the Arctic sea ice is sensitive to model configuration; e.g. under the same bromine loading, $\mathrm{Br}_{Y}$ in the Arctic spring boundary layer in the p-TOMCAT control run (i.e. with all bromine emissions) can be 2 times that in the UKCA control run. Despite the model differences, both model control runs can successfully reproduce large bromine explosion events (BEEs) and ODEs in polar spring. Model-integrated tropospheric-column $\mathrm{BrO}$ generally matches GOME-2 tropospheric columns within $\sim 50 \%$ in UKCA and a factor of 2 in p-TOMCAT. The success of the models in reproducing both ODEs and BEEs in the Arctic indicates that the relevant parameterizations implemented in the models work reasonably well, which supports the proposed mechanism of SSA production and bromide release on sea ice. Given that sea ice is a large source of SSA and halogens, changes in sea ice type and extent in a warming climate will influence Arctic boundary layer chemistry, including the oxidation of atmospheric elemental mercury. Note that this work dose not necessary 
rule out other possibilities that may act as a source of reactive bromine from the sea ice zone.

\section{Introduction}

Climatological data show that mean surface ozone across the Arctic is $\sim 5$ ppbv higher than that in the Antarctic (Helmig et al., 2007a), reflecting the impact of anthropogenic emissions of ozone precursors such as $\mathrm{NO}_{x}\left(=\mathrm{NO}+\mathrm{NO}_{2}\right)$ and volatile organic compounds (VOCs) in the Northern Hemisphere (NH; e.g. Law and Stohl, 2007; Quinn et al., 2008; Walker et al., 2012; Ancellet et al., 2016). For a specific location, the surface ozone depends on multiple factors, including the elevation above sea level (a.s.l.), proximity to the coast, human influence, and processes such as photochemical production and loss rates and dry deposition. Over the past several decades, Arctic sea ice extent has been declining (e.g. Cavalieri and Parkinson, 2012; Laxon et al., 2013; Olonscheck et al., 2019) and thinning (Lindsay and Zhang 2005; Kwok and Rothrock, 2009). The rapid disappearance of summer multi-year sea ice means there will be more young sea ice in the following winter and spring, which will potentially affect the exchange of chemical compounds (both gaseous and particulate-phase) between the ocean, sea ice, and the atmosphere. A modelling study shows that the alteration of surface albedo alone, in a scenario of a sea-icefree Arctic summer, can significantly alter the atmospheric oxidizing capacity at high latitudes, including the concentrations of ozone and the hydroxyl radical $(\mathrm{OH}$; Voulgarakis et al., 2009a). Therefore, the rapid change in the Arctic environment in a warming climate may greatly affect Arctic near-surface ozone concentration, seasonality, and long-term trend (Tarasick and Bottenheim 2002).

Observations of anomalously low boundary layer ozone at coastal sites in the Arctic spring have been reported (Bottenheim et al., 1986; Barrie et al., 1988). An ozone depletion event (ODE) often refers to surface ozone volume mixing ratio (VMR) drops $<10$ ppbv or even near-zero levels. ODEs are mostly found in association with strongly enhanced bromine, so-called bromine explosion events (BEEs). The enhanced bromine monoxide ( $\mathrm{BrO})$ can extend from near the surface to a height of a few $\mathrm{km}$, as has been frequently observed by in situ measurements (e.g. Liao et al., 2011, 2012; Buys et al., 2013; Schultz et al., 2017 and references therein), ground-based remote sensing (e.g. multi-axis differential optical absorption spectroscopy, MAX-DOAS; Frieß et al., 2011; Zhao et al., 2016), and satellite-based remote sensors (e.g. Wagner and Platt, 1998; Theys et al., 2011). Analyses of Arctic transport (Bottenheim and Chan 2006; Liu et al., 2013) as well as in situ measurements (Bottenheim et al., 2009; Jacobi et al., 2010; Seabrook et al., 2013) suggest that the near-surface ozone minimum in spring is not limited to coastal sites but covers much of the Arctic basin, indicating that the sources of bromine are mainly sea-ice-related (e.g. Simpson et al., 2007a; Abbatt et al., 2012). However, the dominant sources of bromine during ODEs or BEEs are still under debate. Proposed candidates for reactive-bromine release include e.g. frost flowers (Kaleschke et al., 2004), first-year sea ice (Skov et al., 2004; Simpson et al., 2007b), sea salt aerosol (SSA) produced from blowing snow (Yang et al., 2008), snowpack (Pratt et al., 2013; Custard et al., 2017), and SSA from open leads (e.g. Kirpes et al., 2019). For example, Pratt et al. (2013) showed that the snowpack is a source of reactive halogens. Custard et al. (2017) provided further evidence that snowpack activation occurs. In addition, stratospheric $\mathrm{BrO}$ intrusions in association with downward transport of air masses from the lower stratosphere also affect polar free-tropospheric $\mathrm{BrO}$ (Salawitch et al., 2010). Global chemical models have been used to test chemical schemes for interpreting or reproducing observed spring ODEs and BEEs. For instance, Toyota et al. (2011) and Falk and Sinnhuber (2018) focused on snowpack-released bromine, while Yang et al. (2010) and Choi et al. $(2012,2018)$ considered blowing-snow-sourced bromine. Box (or 0-D) models are used for process studies such as heterogeneous reactions on various saline particles including SSA, frost flowers, and snowpack (Fan and Jacob 1992; Tang and McConnell, 1996; Michalowski et al., 2000; Evans et al., 2003). One-dimensional models have also been developed with a focus on the exchange of gaseous-phase halogens between the air in the boundary layer and the snowpack and boundary layer ODEs and BEEs (Saiz-Lopez et al., 2008; Thomas et al., 2011, 2012; Cao and Gutheilm 2013; Cao et al., 2016).

Recent winter cruise data from the Weddell Sea, Antarctica, confirm that the sea ice surface is a large source of sea salt aerosol (Frey et al., 2020; Yang et al., 2019). Like the open-ocean-sourced sea spray, the sea-ice-sourced SSA is also a large reservoir of various chemical compounds, including inorganic halogens. Through heterogeneous reactions, bromide $\left(\mathrm{Br}^{-}\right)$and chloride $\left(\mathrm{Cl}^{-}\right)$can be activated and released to the air to form a large source of inorganic halogens (Fan and Jacob, 1992, Vogt et al., 1996), and the consequences may induce polar boundary layer bromine explosion events and ozone depletion events (Simpson et al., 2007a; Abbatt et al., 2012).

SSA bromide data collected in the NH mid-to-low latitudes show that bromide is largely depleted with respect to sodium without a clear seasonal cycle of the depletion strength (Sander et al., 2003). This is attributed to the air pollution and acidification of SSA in the NH. However, in the Southern Ocean of Antarctica, where the air is less polluted, a seasonally varying bromide depletion strength is observed (Ayers et al., 1999; Legrand et al., 2016) with maximum depletion factors in later spring to early summer and a minimum in winter. Global chemistry models with a detailed tropospheric-bromine scheme show that open-ocean-sourced bromine can cause tropospheric-ozone loss of $\sim 5 \%$ at mid- 
to-low latitudes and up to $15 \%-30 \%$ at high latitudes (Yang et al., 2005; Parrella et al., 2012). Model runs with sea-icesourced bromine implemented show that an additional $10 \%-$ $25 \%$ ozone loss can be simulated in polar spring (Yang et al., 2010). Global models with a relatively coarse horizontal resolution of a few degrees by a few degrees can explain large-scale (e.g. $>\sim 500 \mathrm{~km}$ ) ODEs and BEEs in both polar regions (Theys et al., 2011; Zhao et al., 2016; Legrand et al., 2016; Choi et al., 2018). However, no systematic validation against measured ozone and $\mathrm{BrO}$ in the Arctic and the Antarctic has been presented. This is important to examine and refine the bromine scheme implemented in models, especially in the polar regions.

Most current global-scale chemistry models do not have sea-ice-sourced halogens included. A recent assessment of tropospheric-ozone performance in current global models is mainly focused on mid-latitudes (Young et al., 2018), as are most global ozone seasonality studies (e.g. Derwent et al., 2016; Parrish et al., 2016). Previous multi-model assessments of Arctic surface ozone in global chemistry transport models (CTMs) gave quite different implications on the role of halogens. For instance, Monks et al. (2015) and early modelling work by Shindell et al. (2008) showed over-prediction of surface ozone at Barrow in spring, implying a result of missing halogen chemistry. However, Emmons et al. (2015) showed a general model under-prediction in April compared with ozone-sondes, suggesting that the halogen-induced bias may not be pervasive in the Arctic troposphere. In very recent modelling work focusing on polar tropospheric halogens (Fernandez et al., 2019), photochemical release of molecular bromine, chlorine, and interhalogens from the sea ice surface as well as iodine biologically produced underneath and within porous sea ice is considered. However, relatively little is known about model skill in reproducing polar spring boundary layer ozone, especially on short hourly and daily timescales, leaving a large gap in our understanding of the global ozone budget in the polar regions.

Although observations of surface ozone and tropospheric vertical ozone profiles are limited in the Arctic, existing data clearly show that there is a spring ozone maximum at inland sites such as Pallas, Finland (e.g. Hatakka et al., 2003), and Summit, Greenland (3208 m a.s.l.; e.g. Helmig et al., 2007b). It has been proposed that this spring ozone maximum, also seen at other high-latitude locations (e.g. Monks, 2000), is attributable to reduced ozone photo-dissociation and dry deposition in winter, balanced by increased stratospheric ozone intrusions in spring following the break-up of the polar vortex in the lower stratosphere (e.g. Laurila, 1999; Helmig et al., 2007a, b). However, at coastal sites, ozone is observed to be heavily depleted during spring. Moreover, the nearsurface ozone minimum observed in spring is not limited to coastal sites but covers much of the Arctic boundary layer (Liu et al., 2013; Hardacre et al., 2015). Can global models with state-of-the-art bromine chemistry reproduce this panArctic spring ozone depletion? What is the dominant factor that causes spring ODEs and BEEs? These are the two key questions addressed in this study.

We employ multi-year integrations in two global chemistry models (the parallelised-Tropospheric Offline Model of Chemistry and Transport - p-TOMCAT - chemistry transport model and the United Kingdom Chemistry and Aerosol - UKCA - chemistry-climate model) and perform comparisons to observations of surface ozone, vertical ozone profiles, and GOME-2 tropospheric-column $\mathrm{BrO}$ in order to validate the effect of these modelled processes on ozone depletion and $\mathrm{BrO}$ enhancement.

This work is undertaken in the framework of International Arctic Systems for Observing the Atmosphere (IASOA), whose mission is to advance coordinated and collaborative research objectives using data from independent Arctic atmospheric observatories (Uttal et al., 2016). This is a modelling-based study of the pan-Arctic surface zone. The surface ozone climatology data used in this study are from Summit, Greenland $\left(72.6^{\circ} \mathrm{N}, 38.5^{\circ} \mathrm{W}\right)$; Pallas, Finland $\left(68.0^{\circ} \mathrm{N}, 24.1^{\circ} \mathrm{E}\right)$; Barrow, USA $\left(71.3^{\circ} \mathrm{N}\right.$, $\left.156.6^{\circ} \mathrm{W}\right)$; Alert, Canada $\left(82.5^{\circ} \mathrm{N}, 62.3^{\circ} \mathrm{W}\right)$; Tiksi, Russia $\left(71.6^{\circ} \mathrm{N}, 128.9^{\circ} \mathrm{E}\right)$; and Villum Research Station (VRS) at Station Nord, Greenland $\left(81.4^{\circ} \mathrm{N}, 16.4^{\circ} \mathrm{W}\right)$. Ozonesonde data are from three Canadian sites: Resolute $\left(74.7^{\circ} \mathrm{N}\right.$, 95. $\left.0^{\circ} \mathrm{W}\right)$, Eureka $\left(80.1^{\circ} \mathrm{N}, 86.4^{\circ} \mathrm{W}\right)$, and Alert. Retrievals of tropospheric-column BrO from the GOME-2 instrument, including maps and subsetted data for each site, and groundbased MAX-DOAS BrO at Eureka are also used. Figure 1 shows the locations of these sites. Measurements are described briefly in Sect. 2. Model experiments are described in Sect. 3. The results of the model data comparison are presented in Sect. 4. Discussions and summary are in Sects. 5 and 6 , respectively.

\section{Measurements}

\subsection{Surface ozone and ozone-sondes}

Surface ozone data are retrieved from the World Data Centre for Reactive Gases (WDCRG) and archived at the NOAA Global Monitoring Laboratory (https://www.esrl.noaa.gov/ gmd/ozwv/surfoz/data.html, last access: 1 December 2020). The measurements of surface ozone are made by several brands of dual-cell UV absorption monitors, which relate UV absorption to ozone concentration following the BeerLambert law. Details can be found in the articles VRS in Skov et al. (2004, 2020) and Alert in Bottenheim et al. (2002) or in review articles by e.g. Gaudel et al. (2018), Oltmans et al. (2010), and Cooper et al. (2014). In general, the technique has a detection limit of about 1 ppbv and an uncertainty (95\% confidence interval) of about 1 ppbv for VMRs below 10 ppbv and about 2 ppbv for more typical surface VMRs of 30-40 ppbv (Galbally et al., 2013; Tarasick et al., 2019a). 


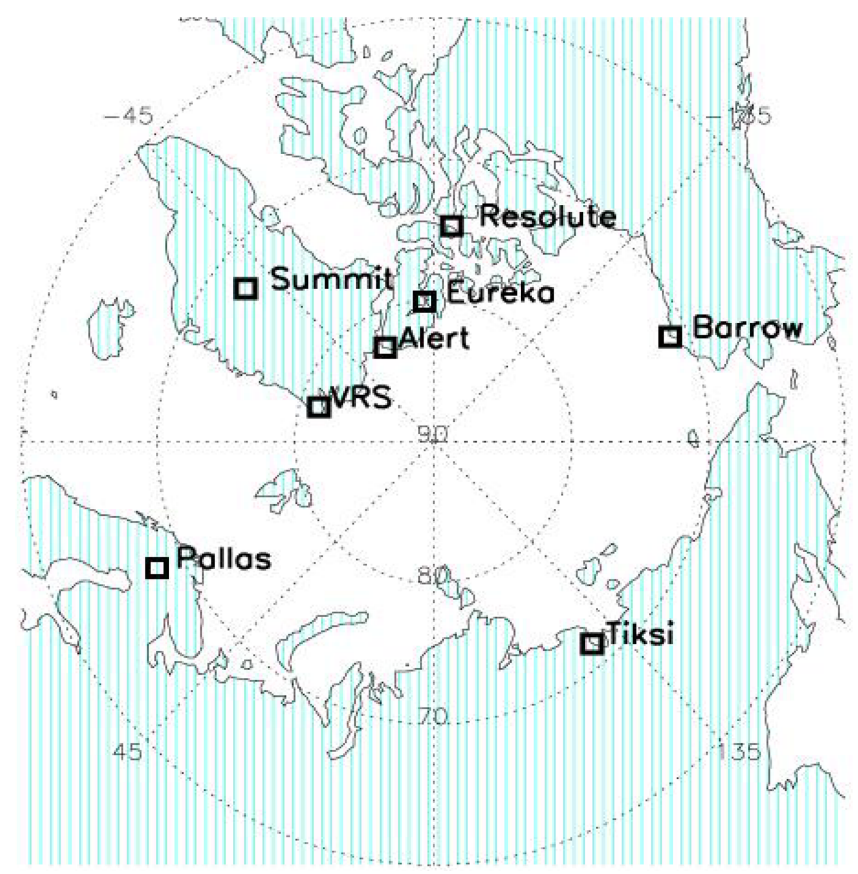

Figure 1. Map of the Arctic showing the locations of the eight Arctic sites where surface ozone and/or ozone-sonde data are used in this study.

Ozone-sonde data from the three Canadian stations used here can be found at the World Ozone and Ultraviolet Radiation Data Centre (WOUDC). During the period of interest here, all ozone-sondes used were electrochemical concentration cells (ECCs; Komhyr, 1969), manufactured by Environmental Science (EN-SCI) Corp. All sondes used the conventional neutral-buffered $1 \%$ potassium iodide sensing solution. The data records of the Canadian sites have recently been re-evaluated (Tarasick et al., 2016). Based on the typical ozone sensor response time of 25-40 s (Smit and Kley, 1998) and assuming a typical balloon ascent rate of 4-5 $\mathrm{m} \mathrm{s}^{-1}$, the ozone-sondes have a vertical resolution of about 100-200 m. Measurement precision is $\pm 3 \%-5 \%$, and the overall uncertainty in ozone VMRs is less than $10 \%$ in the troposphere (Kerr et al., 1994; Smit et al., 2007; Tarasick et al., 2016, 2019a, 2020).

Ozone-sonde releases are normally once per week, although additional releases are often scheduled during observational campaigns in the Arctic spring. Despite their low frequency of observation compared to surface monitoring, ozone-sondes have been used successfully to study boundary layer processes like ODEs (e.g. Bottenheim et al., 2002; Tarasick and Bottenheim, 2002) and long-range transport (e.g. Oltmans et al., 2010; He et al., 2011; Tarasick et al., 2019b).

\subsection{Complementary datasets}

In addition to the ozone measurements, several other datasets are employed in this study: tropospheric columns of $\mathrm{BrO}$ from the Global Ozone Monitoring Experiment-2 (GOME-2; Callies et al., 2000) instrument on board the Meteorological Operational Satellite-A (MetOp-A) and lower-tropospheric profiles of $\mathrm{BrO}$ from ground-based multi-axis differential optical absorption spectroscopy (MAX-DOAS) at Eureka, Canada.

The GOME-2 tropospheric columns of $\mathrm{BrO}$ used in this study are described in further detail by Blechschmidt et al. (2016). In summary, tropospheric BrO vertical columns $\left(\mathrm{VCD}_{\text {trop }}\right)$ were obtained based on the approach of Begoin et al. (2010) for deriving BrO total slant column densities by the DOAS (Platt, 1994) method using a 336-347 nm fitting window (Afe et al., 2004) and on Theys et al. (2011) for stratospheric correction. The latter involves the use of a climatology of stratospheric vertical column densities (VCDs) of BrO estimated by the BASCOE (the Belgian Assimilation System for Chemical ObsErvations) chemical transport model (Errera et al., 2008; Viscardy et al., 2010). The stratospheric VCDs were converted to slant columns by application of a stratospheric-air-mass factor and then subtracted from total slant columns. A tropospheric-air-mass factor was applied for conversion to $\mathrm{VCD}_{\text {trop }}$ assuming that all $\mathrm{BrO}$ is located and well mixed within the lowermost $400 \mathrm{~m}$ of the troposphere over ice or snow with a surface reflectance of 0.9 . A sensitivity study for a BEE case showed that the GOME-2 tropospheric $\mathrm{BrO}$ column has a moderate sensitivity to the stratospheric $\mathrm{BrO}$ column; e.g. a variation in the $\mathrm{VCD}_{\text {strat }}$ of $15 \%-30 \%$ leads to a change in $\mathrm{VCD}_{\text {trop }}$ of about 0.5 to $1 \times 10^{13}$ molecules $\mathrm{cm}^{2}$, respectively (Zhao et al., 2016). The influence of clouds on GOME-2 BrO retrievals and the implications for studying bromine explosion events using GOME2 data are discussed in Blechschmidt et al. (2016). GOME-2 tropospheric $\mathrm{BrO}$ column maps $\left(0.5 \times 0.5^{\circ}\right.$ grid $)$ and time series based on subsetted data of $\mathrm{VCD}_{\text {trop }}$ (all measurements having their centre within a distance of $<40 \mathrm{~km}$ from the ground station) at the Resolute, Eureka, and Alert sites are used here.

MAX-DOAS measurements were performed at the Polar Environment Atmospheric Research Laboratory (PEARL) Ridge laboratory $(610 \mathrm{~m})$ in Eureka. Spectra were recorded in the UV using a grating spectrometer (1200 groves $/ \mathrm{mm}$ grating) with a cooled $(200 \mathrm{~K})$ charge-coupled device (CCD) detector at $0.4-0.5 \mathrm{~nm}$ resolution. Elevation angles of 30, $15,10,8$, and $5^{\circ}\left(6^{\circ}\right.$ in 2011$)$ were used in the elevation scans, and measurements were only taken with solar elevation above $4^{\circ}$. Differential slant column densities (dSCDs) of $\mathrm{BrO}$ and the oxygen dimer $\left(\mathrm{O}_{4}\right)$ were retrieved using the settings described in Zhao et al. (2016). Reference spectra for the DOAS analysis were interpolated from zenith measurements taken before and after each elevation scan. The dSCDs were converted to profiles using a two-step optimal- 
estimation method (Frieß et al., 2011). First, aerosol extinction profiles were retrieved from $\mathrm{O}_{4} \mathrm{dSCDs}$, and then the extinction profiles were used as a forward model parameter in the $\mathrm{BrO}$ retrieval. The retrievals were performed on a $0-4 \mathrm{~km}$ altitude grid with $0.2 \mathrm{~km}$ resolution. Due to the altitude of the instrument $(610 \mathrm{~m})$ and the lack of low or negative elevation angles, the retrieved profiles are only sensitive to well-mixed $\mathrm{BrO}$ in a deep boundary layer and to lofted $\mathrm{BrO}$ events.

\section{Models}

A global chemistry transport model, p-TOMCAT, and a global chemistry climate model, UKCA, are used in this study. The offline p-TOMCAT used a $6 \mathrm{~h}$ ERA-Interim dataset to drive its winds, temperature and moisture. The ERA-Interim data were taken from the European Centre for Medium-Range Weather Forecasts (ECMWF; Dee et al., 2011). In this study, a nudged UKCA version is used to ensure a model meteorological field close to the real situation for data-model comparison. We follow the work of Telford et al. (2008) with a standard nudging relaxation parameter $G=1 / 6 \mathrm{~h}^{-1}$, whose value lies within the range of relaxation parameters used by other models (Jeuken et al., 1996; Hauglustaine et al., 2004; Schmidt et al., 2006). We used the 6-hourly ERA-Interim winds and temperature to constrain the UKCA model's dynamical field. However, nudging is not applied to all levels, with no nudging being applied above level $50(\sim 48 \mathrm{~km})$ or below level $12(\sim 2.9 \mathrm{~km}$; the actual height varies depending on the orography). To avoid instability of the model, moisture is not nudged to reanalysis data; therefore it is free running.

Both models applied a non-local boundary layer mixing scheme, but p-TOMCAT is based on the parameterization of Holtslag and Boville (1993), while UKCA is based on the scheme of Lock et al. (2000). In terms of convective mass flux, p-TOMCAT applied the scheme of Tiedtke (1989), which has been updated to increase convective transport to the mid and upper troposphere (Barret et al., 2010; Feng et al., 2011), and UKCA applied the bulk convection model of Gregory and Rowntree (1990). As shown in a multi-model inter-comparison in the tropics, these two models showed different behaviour in terms of deep-convective transport of tropical boundary layer tracers (Hoyle et al., 2011). The clouds and precipitation schemes are also different between the two models (Russo et al., 2011), resulting in different wash-out rates for aerosols and soluble chemical compounds. The precipitation bias in the p-TOMCAT model (Giannakopoulos et al., 2004) is remedied by applying a correction to force the simulated precipitation values towards Global Precipitation Climatology Project (GPCP) observations (Adler et al., 2003) following the work in Legrand et al. (2016). This corrected precipitation scheme has been used in recent sea salt aerosol modelling works (Rhodes et al., 2017; Yang et al., 2019). However, precipitation in UKCA is free running; therefore the two models may have different wet removal rates for soluble gaseous-phase species. Details of other model configurations, mainly in the chemistry scheme used, are described in Sect. 3.1 for p-TOMCAT and Sect. 3.2 for UKCA.

In addition to the two global chemistry models, we used back-trajectories from the NOAA Hybrid Single-Particle Lagrangian Integrated Trajectory (HYSPLIT) model (Stein et al., 2015; Rolph et al., 2017) for air mass history study of the selected ODE case in Sect. 4.2.

\section{$3.1 \quad$-TOMCAT model}

The Cambridge parallelised-Tropospheric Offline Model of Chemistry and Transport (p-TOMCAT) has a horizontal resolution of $2.825^{\circ} \times 2.825^{\circ}$ (longitude $\times$ latitude) and 31 vertical layers from the surface to about $10 \mathrm{hPa}(\sim 31 \mathrm{~km})$ at the top layer. Sea ice coverage and sea surface temperatures are monthly and taken from the Hadley Centre Sea Ice and Sea Surface Temperature dataset (Rayner et al., 2003). The pTOMCAT non-local vertical diffusion scheme is taken from the National Centre for Atmospheric Research Community Climate Model, Version 2. This scheme determines the planetary boundary layer (PBL) height explicitly and takes account of large-scale eddy transport that can occur throughout the boundary layer even when part of it is statically stable. Implementation and validation of the PBL scheme was carried out by Wang et al. (1999). The model behaviour in terms of vertical mixing of atmospheric tracer and air mass transport has been reported in Russo et al. (2011) and Hoyle et al. (2011).

The ozone photochemistry scheme applied to the model has been detailed in previous studies (Law et al., 1998, 2000; Savage et al., 2004), with updates including an isoprene chemistry scheme, same as the one implemented in the UKCA model by Young et al. (2009) according to the method of Pöschl et al. (2000); a hydrolysis reaction of $\mathrm{N}_{2} \mathrm{O}_{5}$ on aerosols and cloud droplets (Yang et al., 2005); a tropospheric-bromine scheme involving both gaseous-phase reactions (Yang et al., 2005) and heterogeneous reactions (Yang et al., 2010); and a Fast-J photolysis scheme developed by Voulgarakis et al. (2009b), which is not used in this study. They found that $\mathrm{N}_{2} \mathrm{O}_{5}$ hydrolysis can cause net $\mathrm{NO}_{x}$ loss at high latitudes by up to $60 \%$ in the Northern Hemisphere and $\sim 80 \%$ in the Southern Hemisphere (Yang et al., 2005). They found that including halogen-related heterogeneous reactions on aerosols and cloud droplets can significantly increase polar $\mathrm{BrO}$ partitioning by a factor of $\sim 3$ (Yang et al., 2010). This heterogeneous reaction scheme for halogen reactivation was also implemented to the UKCA model (Yang et al., 2014; Dennison et al., 2019; Ming et al., 2020).

Ozone is dry-deposited in the bottom model layer with dry-deposition velocity inferred from the study of Ganzeveld and Lelieveld (1995) by Giannakopoulos (1998). The original dry-deposition velocity over ocean and snow 
( $\left.=0.05 \mathrm{~cm} \mathrm{~s}^{-1}\right)$ is reduced to $0.01 \mathrm{~cm} \mathrm{~s}^{-1}$ in this study following recent modelling work by Hardacre et al. (2015) and Luhar et al. (2018) as well as Helmig et al. (2007a). Since p-TOMCAT only covers part of the stratosphere with a top layer height of $\sim 31 \mathrm{~km}$, a simplified stratospheric-chemical scheme has to be used, including a pre-prescribed top boundary condition for ozone. Therefore, the p-TOMCAT model is quite different from the UKCA model in the upper troposphere and lower stratosphere. However, it is unlikely that the downwards transport of air mass in the polar region may significant influence near-surface bromine. Recent changes to p-TOMCAT, the tropospheric-halogen-chemistry scheme, include updates to dry- and wet-deposition schemes as reported in Legrand et al. (2016). Tropospheric bromine comes from three emission sources: (i) very-short-lived substances (VSLSs) of bromocarbons following the work of Warwick et al. (2006) with reduced flux for $\mathrm{CH}_{2} \mathrm{Br}_{2}$ (Yang et al., 2014), (ii) open-ocean sea spray (Yang et al., 2005, Breider et al., 2009; Parrella et al., 2012), and (iii) sea-ice-sourced SSA in polar regions following the work of Yang et al. $(2008,2010$, 2019). Here we define total inorganic bromine $\mathrm{Br}_{Y}=\mathrm{HOBr}$ $+\mathrm{HBr}+\mathrm{BrO}+\mathrm{Br}+\mathrm{BrONO}_{2}+\mathrm{BrNO}_{2}+2 \cdot \mathrm{Br}_{2}+\mathrm{BrCl}$.

A process-based SSA transport dry- and wet-deposition scheme has been implemented in the model by Levine et al. (2014) based on the work of Reader and McFarlane (2003). The open-ocean sea spray emission scheme follows Jaeglé et al. (2011), and the sea-ice-sourced SSA scheme follows the latest work of Yang et al. (2019). Both open-oceansourced and sea-ice-sourced SSA (denoted as OO and SI, respectively) are tagged in 21 size bins covering dry $\mathrm{NaCl}$ diameter of $0.02-20 \mu \mathrm{m}$ in order to track their history for online calculation of their surface density for heterogeneous reaction rates.

All parameters applied in this study for the Arctic SSA simulation are directly taken from our recent SSA modelling work by Yang et al. (2019), including a 3.5 times Antarctic snow salinity for the Arctic. The Antarctic Weddell Sea cruise data (Frey et al., 2020) are a probability of surface snow salinity, which is different to the constant salinity value $(=0.3 \mathrm{psu}$, practical salinity unit) used in Legrand et al. (2016), Zhao et al. (2017), and Rhodes et al. (2017). The trebled snow salinity assumption is taken from Yang et al. (2008) to reflect the likelihood that Arctic snow is more saline than in the Antarctic due to reduced precipitation. This assumption is partly justified by surface snow $\left[\mathrm{Cl}^{-}\right]$concentrations observed in the two poles. For instance, an averaged surface snow (top $1-2 \mathrm{~cm}$ ) $\left[\mathrm{Cl}^{-}\right]$ concentration of $368 \mu \mathrm{M}$ is derived from the Weddell Sea, Antarctic (https://ramadda.data.bas.ac.uk/repository/entry/ show? entryid=853dd176-bc7a-48d4-a6be-33bcc0f17eeb, last access: 1 December 2020). In the Arctic, Pratt et al. (2013) reported a mean surface $\left[\mathrm{Cl}^{-}\right]$concentration of $1121 \mu \mathrm{M}$ (top $1 \mathrm{~cm}$ ) over coastal sea ice near Barrow, Alaska, and Krnavek et al. (2012) reported a much higher surface $\left[\mathrm{Cl}^{-}\right]$concentration of $21058 \mu \mathrm{M}$ over first-year sea ice and $63217 \mu \mathrm{M}$ over multi-year sea ice over a slightly deeper depth of $2-3 \mathrm{~cm}$ below the surface. They are about 3,57 , and 172 times the Weddell Sea surface salinity. The relative higher salinity in the Arctic is partly related to less precipitation as already mentioned. For instance, the depth of snowpack on sea ice near Barrow, Alaska, is in a range of 10-40 cm (Krnavek et al. (2012), while in the Weddell Sea, the mean snow depth over first-year ice (FYI) is 20.9 and $50.0 \mathrm{~cm}$ over multi-year ice (MYI) (Frey et al., 2020).

Other parameters used in this study include a mean snow age of $3 \mathrm{~d}$ for the Arctic following the recent work of Huang and Jaeglé (2017). We assume that the evaporation rate of blowing snow particles is controlled by the moisture gradient between the surface of the particle and the ambient air, an evaporation function of $\frac{\mathrm{d} m_{i}}{\mathrm{~d} t}=d_{i}$, with $m_{i}$ being water mass and $d_{i}$ being diameter of snow particle), i.e. the classic mechanism in Yang et al. (2019). For blowing-snow size distribution, we used a shape parameter $\alpha=3$ and a scale parameter $\beta=37.5 \mu \mathrm{m}$, with an SSA production ratio $N=20$ (i.e. 20 SSA particles formed from one saline wind-blown snow particle during sublimation). This set of parameters corresponds to the SI_Classic_B $\times 20$ run in Yang et al. (2019) and is one of the best parameter sets that matched the Weddell Sea SSA in the size range of $0.4-10 \mu \mathrm{m}$. Also, this set gave the highest SSA mass loading in polar regions (Yang et al., 2019).

To parameterize bromide release from SSA in the Arctic, two different patterns of bromine depletion factor (DF) are used. Table 1 contains a seasonal DF scheme with a maximum value of 0.53 in May and a minimum of 0.07 in December. This seasonal scheme is derived from the bulk SSA bromide depletion strength from Dumont d'Urville (Legrand et al., 2016), Cape Grim, and Macquarie Island (Ayers et al., 1999) in the Southern Hemisphere with a 6-month shift in the phase in order to apply to the NH. Since a similar yearround in situ dataset from the Arctic is not available, we could not justify this seasonal DF pattern, which demands further systematic measurements in the Arctic. As used in previous modelling studies, a size-dependent (non-seasonal) DF scheme for the NH is used for comparison (Supplement Table S1), which is derived from previous work of Yang et al. $(2008,2010)$ and Breider et al. (2009). Note that we simply apply these DF schemes to all SSA emitted and do not distinguish between the open-ocean-sourced and the sea-icesourced SSA in terms of bromide release. However, this approach may introduce bias as freshly emitted sea spray is alkaline with $\mathrm{pH}>8$ and needs acidification first by absorbing sulphate or nitrate before bromide can be liberated to the atmosphere through heterogeneous reactions (e.g. Breider et al., 2009). In contrast, snowpack in the Arctic is largely acidified with $\mathrm{pH}$ of 4-6 due to local acidity contamination (e.g. de Caritat et al., 2005). The difference in initial conditions between sea spray and sea-ice-sourced SSA may affect bromide release in both timing and strength, which has not been considered by our models. Thus, we may overestimate the 
Table 1. Monthly mean SSA bromine depletion factor (DF) scheme applied in the $\mathrm{NH}\left(>45^{\circ} \mathrm{N}\right)$, which is derived from the data in the Southern Hemisphere at Cape Grim $\left(41^{\circ} \mathrm{S}\right)$, Macquarie Island

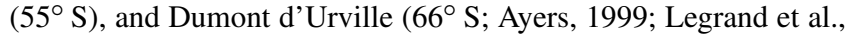
2016). Note that a 6-month shift in the phase is applied to match the $\mathrm{NH}$ seasons. A cut-off dry $\mathrm{NaCl}$ diameter of $10 \mu \mathrm{m}$ is applied (i.e. $\mathrm{DF}=0$ at diameter $>10 \mu \mathrm{m})$.

\begin{tabular}{lr}
\hline Month & DF \\
\hline January & 0.175 \\
February & 0.260 \\
March & 0.445 \\
April & 0.500 \\
May & 0.530 \\
June & 0.383 \\
July & 0.225 \\
August & 0.168 \\
September & 0.192 \\
October & 0.170 \\
November & 0.145 \\
December & 0.07 \\
\hline
\end{tabular}

open-ocean-sourced SSA effect in polar regions as the alkaline buffering effect is not considered.

\subsection{UKCA}

UKCA, a version of the UK Earth System Model with Chemistry and Aerosols, has a dynamical core from the Met Office Unified Model (UM; Morgenstern et al., 2009). A nudged model version 7.3 is used in this study with a horizontal resolution of $3.75^{\circ} \times 2.5^{\circ}$ and 60 vertical layers from the surface to $\sim 84 \mathrm{~km}$. The tropospheric-chemistry scheme was built on the scheme in the p-TOMCAT model but contains a comprehensive stratospheric-chemistry scheme for climate studies (Braesicke et al., 2013; Banerjee et al., 2014; Ming et al., 2020). In terms of SSA production, the same schemes for open-ocean sea spray and for sea-ice-sourced SSA as in the p-TOMCAT are used apart from the fact that the SSA in the UKCA runs is no longer being tagged and tracked for online calculation of heterogeneous reaction rates. Therefore, the emitted SSAs are just used for bromide emission. For heterogeneous reactions, the aerosol surface area density is calculated using the archived monthly climatology aerosol dataset taken from the CLASSIC scheme (Johnson et al., 2010). In the p-TOMCAT model, heterogeneous reactions occur also on cloud droplets, but UKCA does not include such reactions on cloud droplets. Therefore, in the free troposphere, the $\mathrm{BrO}$ partitioning in UKCA may be lower than that in p-TOMCAT, which may result in more soluble inorganic-bromine species being washed out by precipitation in UKCA, as discussed in Sect. 4.

Note that the Unified Model UM-UKCA is a complex chemistry-climate coupling model covering the whole atmosphere, including both troposphere and stratosphere. In many aspects of dynamics and chemistry, it behaves quite differently from the p-TOMCAT CTM. A detailed comparison of model characteristics in vertical mixing and transport of tropical boundary layer tracers was performed by Russo et al. (2011) and Hoyle et al. (2011). The bottom model layer of UKCA, in which chemical compounds such as ozone undergo dry deposition, is $\sim 20 \mathrm{~m}$ thick, while in p-TOMCAT it is $\sim 60 \mathrm{~m}$ thick. All released SSA and bromine (in the form of $\mathrm{Br}_{2}$ ) are put in the bottom model layer before they are further vertically mixed and horizontally transported. These differences in model vertical resolution may affect model output even if other factors are the same. Although the two models are quite different, e.g. in absolute values of chemical compounds, the relative changes in response to changes in bromine loading, for example, are still informative and are our major interest and focus of the discussion.

\subsection{Model experiments}

Table 2 lists major model experiments performed in this study. The two model base runs, pTOMCAT_control and UKCA_control, contain reactive-bromine emissions from both sea-ice-sourced and open-ocean-sourced SSA and VSLS bromocarbons. The pTOMCAT_No_Br run does not include any bromine emission; therefore, it is a model run without bromine chemistry. The pTOMCAT_VSLS and UKCA_VSLS runs only contain bromocarbons as a source of reactive bromine (without bromine from open ocean and sea ice). The pTOMCAT_SI_VSLS and UKCA_SI_VSLS runs only contain sea-ice-sourced SSA and bromocarbons as sources of reactive bromine. Similarly, the pTOMCAT_OO_VSLS and UKCA_OO_VSLS runs only contain sea-spray-sourced SSA and bromocarbons as sources of reactive bromine. By checking the differences between experiments from the same model, we expect to separate individual bromine source contributions to Arctic boundary layer bromine mixing ratio and ozone mixing ratio. Similarly, by checking the differences between the two model responses, we will see model-induced uncertainty, e.g. in both the bromine mixing ratio and ozone mixing ratio. This is because both models employ very similar bromine emissions. Therefore, the differences are mainly due to different model configuration either in their physical aspect - including precipitation, boundary layer dynamics, land use, etc. - or in their chemistry aspect involving key atmospheric species such as ozone or $\mathrm{OH}$ and heterogeneous reactions.

Apart from the pTOMCAT_Fixed_DF run, in which a fixed (non-seasonal) DF scheme is used (Table S1), all model experiments apply the same bromine DF scheme shown in Table 1. A multiple-year integration (2006-2008) is performed, with averaged outputs used as a climatology for comparison. Several spring runs in 2010, 2011, and 2013 are made with more frequent outputs for ODE and BEE comparisons: 1-hourly output frequency in pTOMCAT_control and 3-hourly output frequency in UKCA_control are used 
Table 2. Model experiments with various bromine sources from sea ice (SI), open ocean (OO), and very-short-lived substances (VSLSs) of bromocarbons. Two bromine depletion factor (DF) schemes are used: with seasonal cycle (Table 1) and without seasonal cycle (i.e. using a fixed DF in Table S1).

\begin{tabular}{lllll}
\hline $\begin{array}{l}\text { Models and } \\
\text { experiments }\end{array}$ & $\begin{array}{l}\text { Bromine from } \\
\text { SI }\end{array}$ & $\begin{array}{l}\text { Bromine from } \\
\text { OO }\end{array}$ & $\begin{array}{l}\text { Bromine from } \\
\text { VSLS }\end{array}$ & $\begin{array}{l}\text { DF for } \\
\text { SSA }\end{array}$ \\
\hline pTOMCAT_control & Yes & Yes & Yes & Seasonal \\
pTOMCAT_No_Br & No & No & No & Seasonal \\
pTOMCAT_VSLS & No & No & Yes & Seasonal \\
pTOMCAT_SI_VSLS & Yes & No & Yes & Seasonal \\
pTOMCAT_OO_VSLS & No & Yes & Yes & Seasonal \\
pTOMCAT_Fixed_DF & Yes & Yes & Yes & Fixed \\
UKCA_control & Yes & Yes & Yes & Seasonal \\
UKCA_VSLS & No & No & Yes & Seasonal \\
UKCA_SI_VSLS & Yes & No & Yes & Seasonal \\
UKCA_OO_VSLS & No & Yes & Yes & Seasonal \\
\hline
\end{tabular}

for further analysis and model data comparisons. These years are selected because either significant ODEs or BEEs are observed at one or more sites.

To investigate model sensitivity to key parameters, such as snow salinity, DF, cut-off size, and SSA spectrum, we performed additional model experiments (Table 3) with a range of uncertainty for each parameter. For example, pTOMCAT_high_salinity applies a snow salinity 10 times that of Weddell Sea, and pTOMCAT_low_salinity applies a salinity 1 times that of the Weddell Sea; pTOMCAT_ $2 \times$ DF applies a doubled DF, and pTOMCAT_0.5 $\times$ DF applies a halved DF; pTOMCAT_SSA20 $\mu \mathrm{m}$ applies a large cutoff threshold with a dry $\mathrm{NaCl}$ radius of $20 \mu \mathrm{m}$, and pTOMCAT_SSA5 $\mu \mathrm{m}$ applies a small cut-off threshold of $5 \mu \mathrm{m}$; pTOMCAT_spectrum_1 applies the same parameters as in the control run but a small $N=10$, and pTOMCAT_spectrum_2 applies a different parameter set with $N=$ 1 and different $\alpha, \beta$, and $\frac{\mathrm{d} m_{i}}{\mathrm{~d} t}$ functions (see Table 3); the corresponds to the SI_Base run in Yang et al. (2019). This sensitive experiment is only integrated for 1 year (2007) with results are compared to the pTOMCAT_control run result, as discussed in Sect. 5.

\section{Results}

\subsection{Surface ozone seasonality}

Figure 2 shows observed monthly mean surface ozone VMRs at the six Arctic locations: two inland (Summit and Pallas) and four coastal (Alert, Barrow, Tiksi, and VRS) sites. Spring ozone maxima of $>50 \mathrm{ppbv}$ at Summit and $\sim 45 \mathrm{ppbv}$ at Pallas were observed. However, at coastal sites, springtime ozone is depleted, with low VMRs of 15-20 ppbv, which are comparable to or even lower than their summer ozone minimum in July-August. The summer minimum is thought to be attributable to enhanced ozone photo-dissociation, where $\mathrm{NO}_{x}$ levels are low, and increased dry deposition to plants (e.g. Hatakka et al., 2003; Engvall Stjernberg et al., 2011). At higher-latitude sites such as Alert and VRS that are within the polar dome and surrounded by Arctic tundra with sparse vegetation, there is normally still snow coverage even in midsummer, so the local effect of dry deposition to plants may not be as significant as at Pallas or other sites located further south. However, the long-range transport from lower latitudes of ozone affected by summer plants may result in vegetation having an effect on these sites. For example, the suppressed high-latitude summer ozone in Siberia is related to deposition loss to vegetation during long-range transport into the Arctic (Engvall Stjernberg et al., 2011). Figure 2 also shows that model runs without bromine chemistry (pTOMCAT_No_Br) and with bromocarbons only (pTOMCAT_VSLS) can generate spring ozone maxima at all six sites. When open-ocean-sourced reactive bromine is included (orange line in Fig. 2), the spring ozone peak is reduced significantly. The OO-sourced bromine can cause ozone reductions in all seasons (Fig. 3), with a maximum reduction of $>10 \mathrm{ppbv}$ in April and a minimum reduction (1-2 ppbv) in summer. However, the OO-sourced reactive bromine does not alter the ozone seasonality pattern as the spring ozone peak remains (Fig. 2). On the other hand, sea-ice-sourced reactive bromine (red line in Fig. 2) can significantly perturb the ozone seasonal cycle by removing the spring ozone peak completely. On average, SI-sourced bromine can cause a maximum ozone loss of $>10 \mathrm{ppbv}$ in April at coastal sites (Fig. 3), similar to the OO-sourced reactive-bromine effect. In autumn, SI-sourced bromine only weakly influences the bromine budget and ozone loss. Model runs which contain bromine sources from both OO and SI (black line in Fig. 3) can cause a peak of annual ozone loss of $>25 \mathrm{ppbv}$ (in monthly mean) in April at coastal sites, giving the best match to the observations (Fig. 2). However, inclusion of halogen chemistry leads to severe underestimation of spring ozone at Summit and Pallas. 


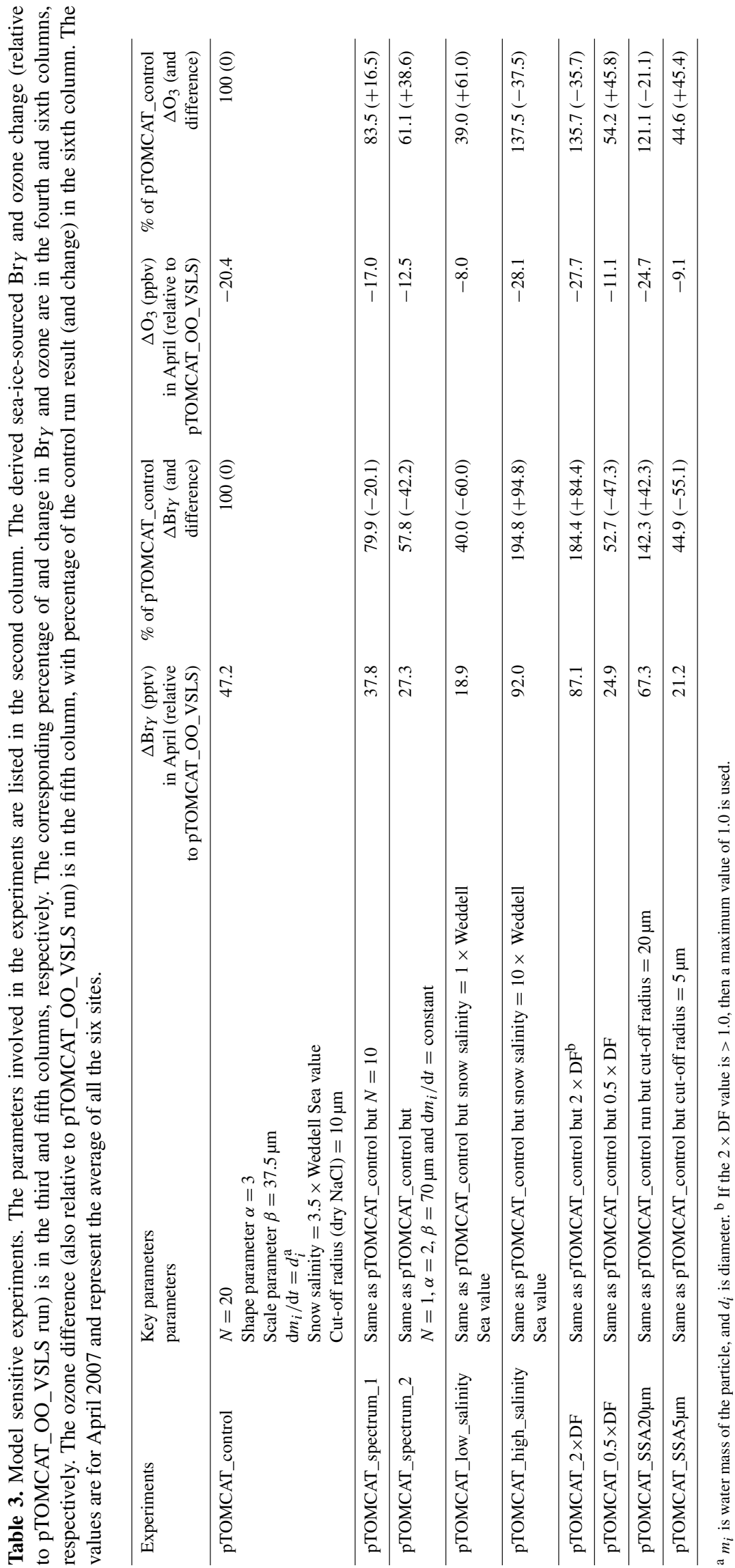



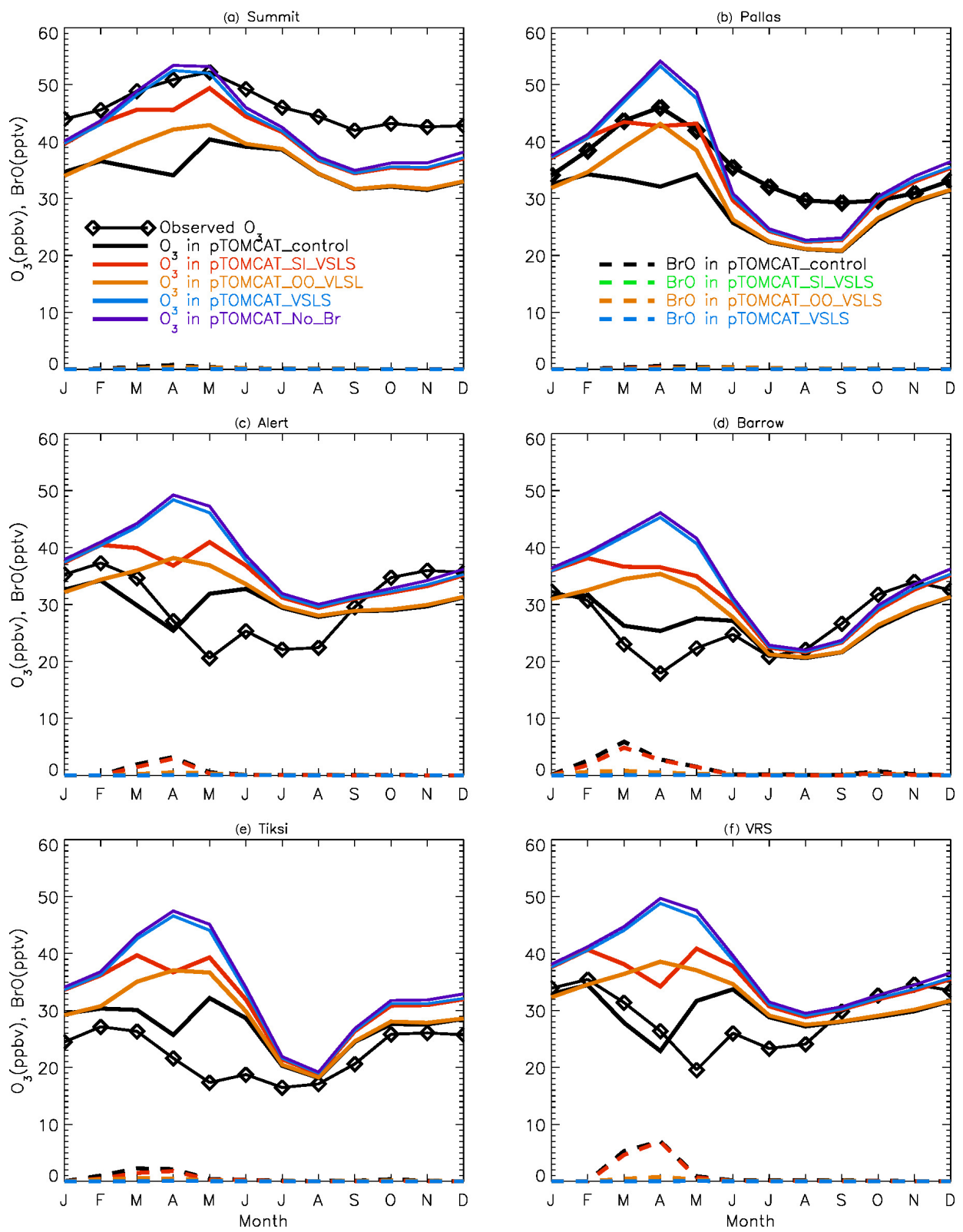

Figure 2. Climatology of monthly mean surface ozone (solid black line with diamond symbols) at six Arctic sites. The observed data are the average of 2000-2016 at Summit, 1995-2012 at Pallas, 1992-2012 at Alert, 1974-2016 at Barrow, 2011-2016 at Tiksi, and 1980-2014 at VRS. Model surface ozone concentrations (VMRs) from various experiments are shown in colourful solid lines with BrO in dashed lines based on an integration of 2006-2008.

A similar effect of the SI- and OO-sourced reactive bromine on surface ozone can be seen in the UKCA runs but with net ozone loss only half of that seen in the p-TOMCAT runs (Fig. S1). As discussed below, this difference is consistent with the difference in total inorganic bromine $\mathrm{Br}_{Y}$ between the two models: a spring surface layer $\mathrm{Br}_{Y}$ maximum of $10-30 \mathrm{pptv}$ is simulated in pTOMCAT_control (Fig. 3), which is about twice that (5-10 pptv) in UKCA_control (Fig. S1). This is consistent with zonal mean (April) $\mathrm{Br}_{Y}$ differences between the two models as shown in Fig. S2.
Since both models employ a very similar bromine emission flux (e.g. SSA production driven by ECMWF data and with the same bromine depletion factor), the difference in $\operatorname{Br}_{Y}$ between the two models is likely due to the difference in removal process of inorganic-bromine species, such as $\mathrm{HBr}, \mathrm{HOBr}, \mathrm{Br}_{2}$, and $\mathrm{BrONO}_{2}$, which are dry- and/or wet-deposited. Previous model simulations have shown that, on the global scale, precipitation wash-out is responsible for $\sim 90 \%$ of the removal of tropospheric $\operatorname{Br}_{Y}$ (Yang et al., 2005). In polar regions, where the precipitation rate is 

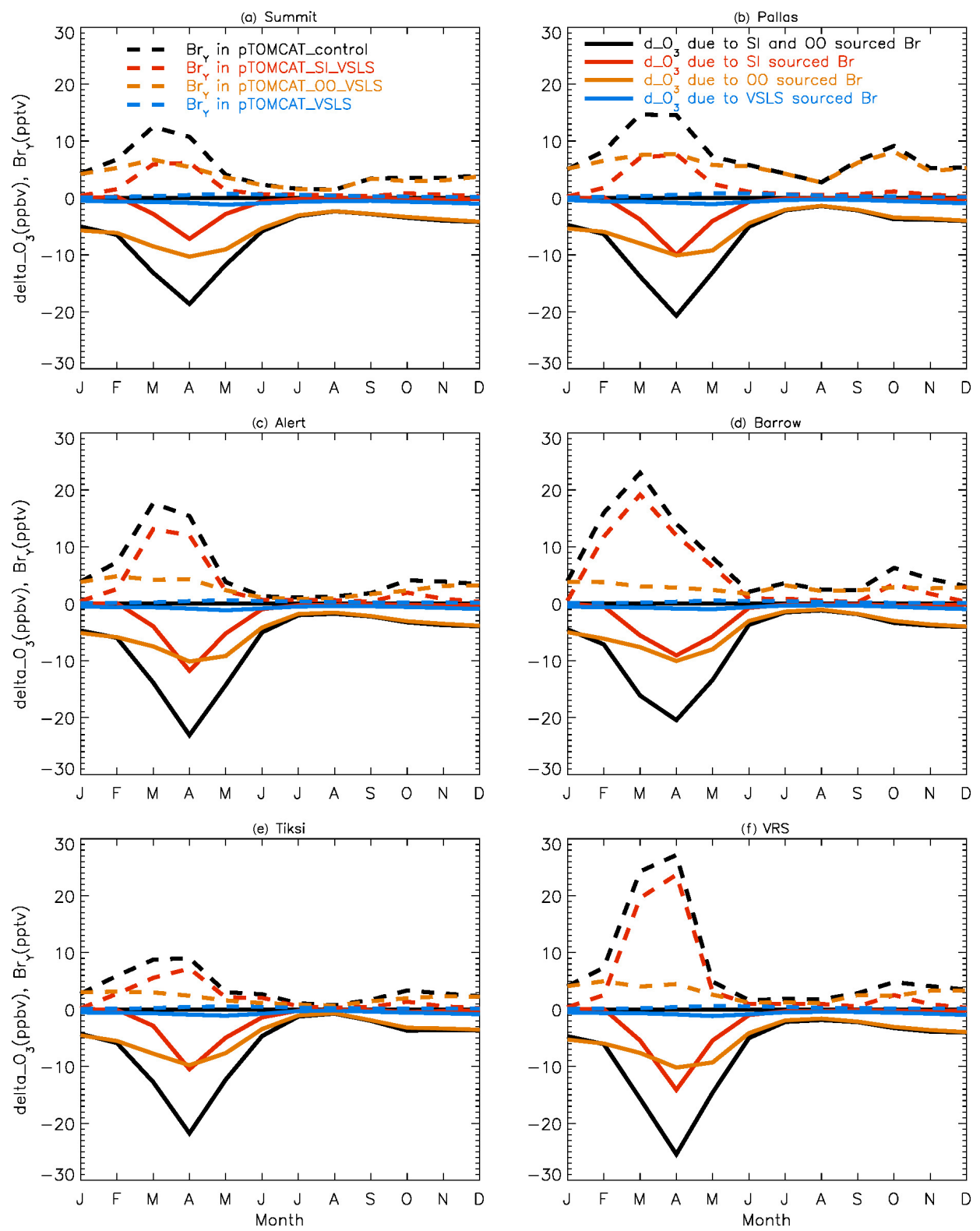

Figure 3. Ozone changes in response to alteration of various bromine sources. E.g. solid black line = pTOMCAT_control - pTOMCAT_VSLS, representing both SI and OO contributions; solid red line = pTOMCAT_control - pTOMCAT_OO_VSLS, representing SI contribution only; solid orange line = pTOMCAT_control - pTOMCAT_SI_VSLS, representing OO contribution only; and solid blue line = pTOMCAT_VSLS - pTOMCAT_No_Br, representing VSLS contribution only. Dashed lines represent total inorganic bromine $\left(\mathrm{Br}_{Y}\right)$ in various model runs: the dashed black line is the pTOMCAT_control run, representing all bromine source contributions; the dashed red line is the pTOMCAT_SI_VSLS run, representing SI and VSLS contributions; the dashed orange line is the pTOMCAT_OO_VLSL run, representing OO and VSLS contributions; and the dashed blue line is the pTOMCAT_VSLS run, representing VSLS contribution only.

relatively low, dry deposition to the surface is another efficient pathway for inorganic-bromine removal in surface layer. The different approaches in chemical scheme applied by the models may also affect inorganic-bromine deposition rate through influencing partitioning of inorganic-bromine species. This is because some species (e.g. $\mathrm{HBr}, \mathrm{HOBr}$ ) are very soluble, while others are not (e.g. $\mathrm{BrO}$ ). A higher $\mathrm{BrO}$ partitioning is expected at a higher ozone concentration and vice versa. Therefore, an overestimated ozone is expected to have a negative feedback to bromine removal and net ozone loss via bromine chemistry. In addition, p-TOMCAT considers heterogeneous reactions on cloud droplets, while UKCA does not; this difference may explain why $\mathrm{BrO}$ partitioning in p-TOMCAT is higher than that in UKCA, especially in the free troposphere, where $\mathrm{BrO}$ partitioning can be as large as $50 \%$ (Fig. S2). In addition, the higher $\mathrm{BrO}$ partitioning in 
p-TOMCAT also attribute less $\mathrm{Br}_{Y}$ removal by dry and wet depositions.

Comparing the surface layer $\mathrm{BrO} / \mathrm{Br}_{Y}$ ratio between the two models (Fig. S3), we can see that both UKCA_control and PTOMCAT_control give a very similar spring peak, with a ratio around $20 \%-30 \%$ at coastal sites, with an exception at VRS, where a ratio of up to $>60 \%$ is simulated in the UKCA_control run. The largest discrepancy appears in summer at some costal sites such as Alert, Tiksi, and VRS, where a second summer peak ratio is simulated in the UKCA_control, which is likely attributed to the obviously overestimated summer ozone concentrations by this model (Fig. S4).

From Figs. 2 and S1 we can see that, on average, surface BrO VMRs at inland sites are smaller than those at coastal sites in both model outputs. For example, in April, mean $\mathrm{BrO}$ is $\sim 1 \mathrm{pptv}$ at Summit and $\sim 0.5 \mathrm{pptv}$ at Pallas; at coastal sites, VMRs are between 2 and 7 pptv in the pTOMCAT_control run. In terms of $\mathrm{Br}_{Y}$, as shown in Fig. 3, in April, both OO- and SI-sourced bromine contributes roughly the same amount (6-8 pptv) at the two inland sites of Summit and Pallas. At coastal sites (Alert, Barrow, Tiksi, and VRS), the OO-sourced bromine contributes one-sixth to half of the SI-sourced $\mathrm{Br}_{Y}$, i.e. 4-5 pptv vs. 8-30 pptv. The large (and small) gradient in $\operatorname{Br}_{Y}$ of the SI-sourced (and the OO-sourced) bromine between inland and coastal sites indicates that SI-sourced bromine is locally sourced, while OO-sourced bromine is remotely transported and thus has a smaller horizontal gradient in VMR. In addition, VSLS bromocarbons only have a relatively small contribution of $\sim 0.5$ pptv $\operatorname{Br}_{Y}$ in spring-summer (Fig. 3), corresponding to an ozone loss of $\sim 1 \mathrm{ppbv}$. As shown in Fig. S7, VSLS contribution to tropospheric $\mathrm{Br}_{Y}$ over the Arctic increases from the near-surface layer $\sim 0.5 \mathrm{pptv}$ (in April and July) to $\sim 2 \mathrm{pptv}$ at $\sim 200 \mathrm{hpa}$. In spring (April), it only accounts for $2 \%-4 \%$ of the total $\operatorname{Br}_{Y}$ in the surface layer and $\sim 40 \%$ at $200 \mathrm{hpa}$; in July, it accounts for $15 \%-20 \%$ in the surface layer and $>60 \%$ at $300-400 \mathrm{hpa}$.

\subsection{Surface ozone frequency distribution}

Figure 4 shows NH summer (July) surface ozone frequency distribution at four coastal sites from both observation and pTOMCAT runs. Climatology clearly indicates a single ozone peak distribution with peak VMRs around $\sim 20 \mathrm{ppbv}$. The pTOMCAT model successfully reproduces this summer single peak distribution frequency, though it overestimates it by a few ppbv, e.g. at Alert and VRS. Similar to what is reflected in Fig. 3, the bromine effect on ozone loss is small, only 1-2 ppbv. In April, the observed ozone distribution frequency is quite different from the summer pattern as a flat distribution across ozone bins is observed with a large ozone depletion fraction at ozone VMRs $<10$ ppbv (Figs. 5 and 6). Although both p-TOMCAT (Fig. 5) and UKCA (Fig. 6) fail to reproduce this flat distribution pattern, the two model runs with SI-sourced bromine implemented can largely reproduce ozone depletion fraction (at ozone $<10 \mathrm{ppbv}$ ). It is interesting to note that although OO-sourced bromine alone can cause April monthly mean ozone to drop by $5-10 \mathrm{ppbv}$ at coastal sites (dashed blue line vs. solid blue line in Figs. 5 and 6), it alone cannot generate any ozone depletion at VMRs $<20$ ppbv, indicating that this remotely sourced bromine to the Arctic is not responsible for coastal ODEs; rather, it only affects background ozone. On the other hand, SI-sourced bromine can cause ozone depletion with a significant fraction of ozone VMRs $<10$ ppbv (dashed orange line in Figs. 5 and 6 ), supporting the suggestion that locally sourced bromine (from sea ice) is responsible for spring ODEs.

As discussed in Sect. 4.3, the failure of models in reproducing the flat ozone distribution in spring is likely attributable to the coarse resolution of the models used. For instance, the horizontal resolutions of $\sim 2.8^{\circ} \times 2.8^{\circ}$ in pTOMCAT and $3.75^{\circ} \times 2.5^{\circ}$ in UKCA mean that any subgrid-scale events will not be captured and represented by the model, and a finer-resolution model may be needed to have better representation of the observations.

\subsection{Spring ozone depletion events}

\subsubsection{Time series}

Figures 7 and 8 show month-long time series of surface ozone at Tiksi (May 2011), Barrow (March 2010), Summit (April 2010), VRS (April 2010), and Alert (April 2010) in observations (black lines), along with pTOMCAT_control output (Fig. 7) and UKCA_control output (Fig. 8) of surface ozone (in red) and $\mathrm{BrO}$ (in blue) from the nearest grid box. Also shown in Figs. 7 and 8 are maximum and minimum ozone taken from five adjacent grid boxes in the bottom model layer of each model with the aim of investigating the effect of model resolution on output. From Fig. 7, we see that both the p-TOMCAT and UKCA models can largely reproduce large ODEs, e.g. the 1-week-long ODE during 711 May 2011 at Tiksi and 10-15 March 2010 at Barrow as well as the 3-day-long ODE during 22-24 April 2010 at VRS. However, the model has a very limited ability to represent small-scale events that last from a few hours to $\sim 1 \mathrm{~d}$. Large discrepancies are found in both timing and magnitude of the ozone depletion. For instance, the $1 \mathrm{~d}$ long ODE on $\sim 22$ April 2010 at Alert is not well captured by the central grid box closest to the site in both models. For example, the p-TOMCAT-simulated minimum ozone occurs later by about $1 \mathrm{~d}$. However, this observed ozone minimum is reproduced if adjacent grid box results are taken into account. In general, the pTOMCAT_control run central grid box surface ozone is significantly correlated with observed ozone, with medium to high correlation coefficients $R$ of 0.68 at Tiksi, 0.49 at Barrow, 0.60 at Summit, and 0.75 at VRS and a small $R=0.22$ at Alert ( $p<0.001$ at all sites; Figure 7 and Table 4, column 2.) The UKCA_control run shows a similar result, with dif- 

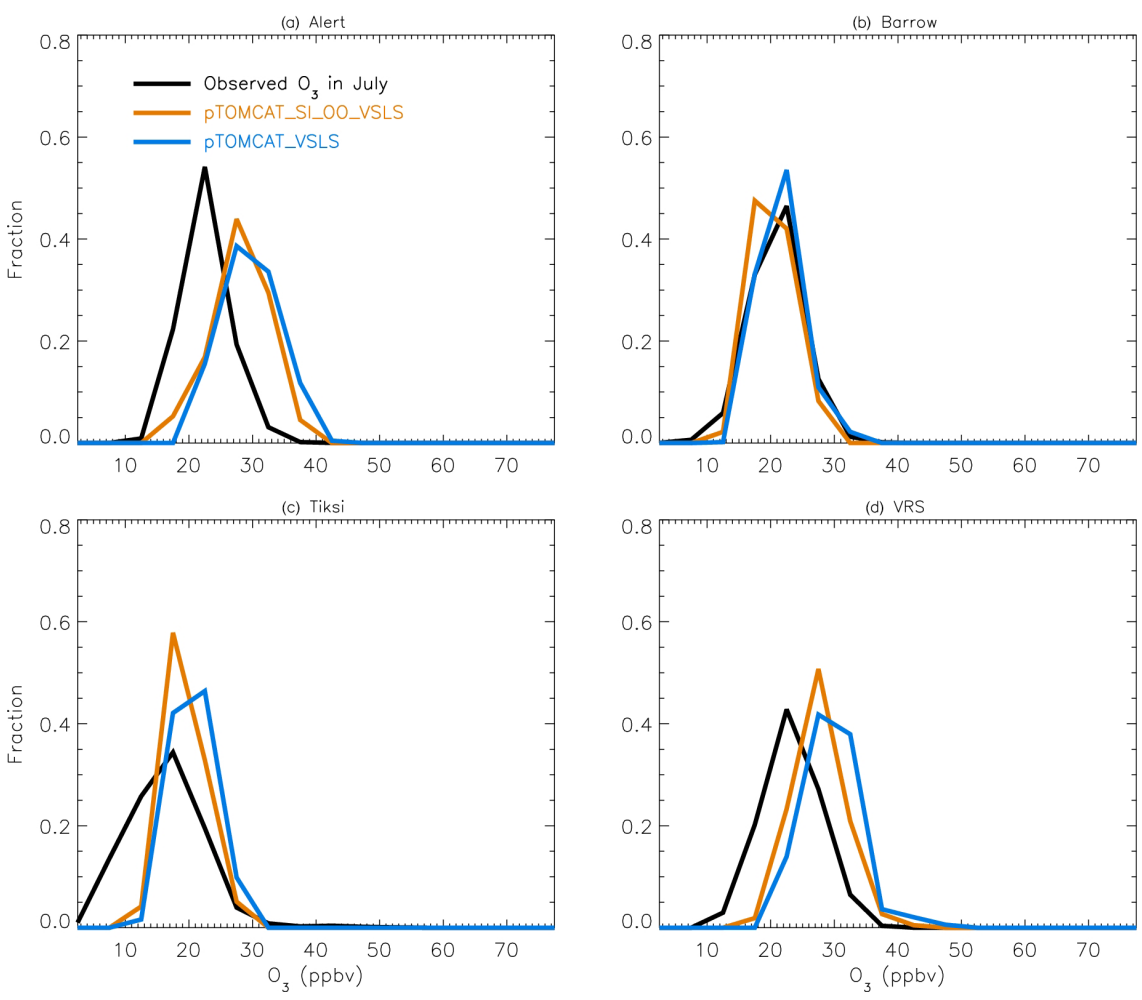

Figure 4. July surface ozone fractional distribution (with a bin interval of $5 \mathrm{ppbv}$ ). The observed fractional distribution is shown by the black line, with the pTOMCAT_control result shown in solid orange and pTOMCAT_VSLS shown in solid blue.
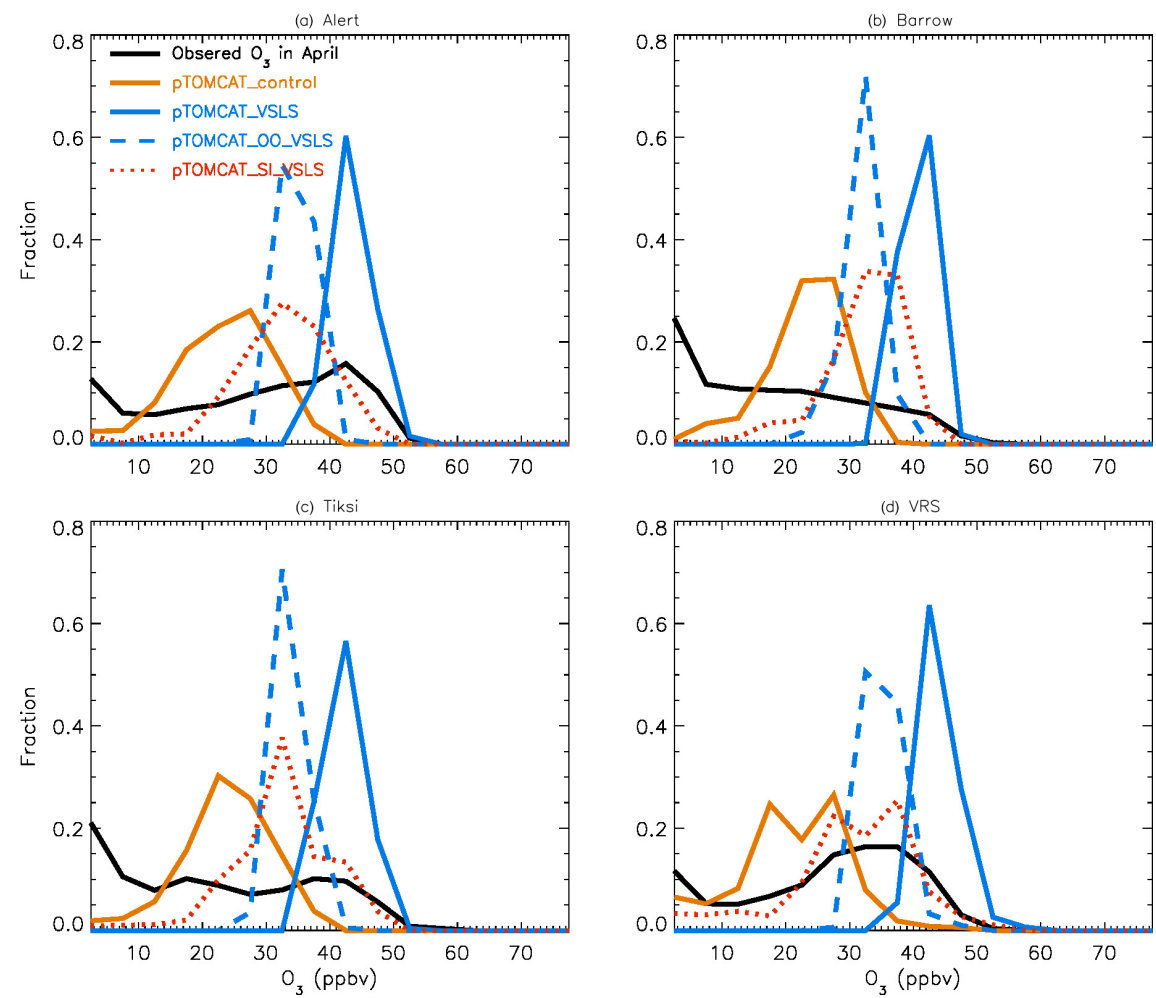

Figure 5. Same as Fig. 4 but for April. Also shown are the pTOMCAT_OO_VSLS results using a dashed blue line and the pTOMCAT_SI_VSLS results shown by a dashed orange line. 

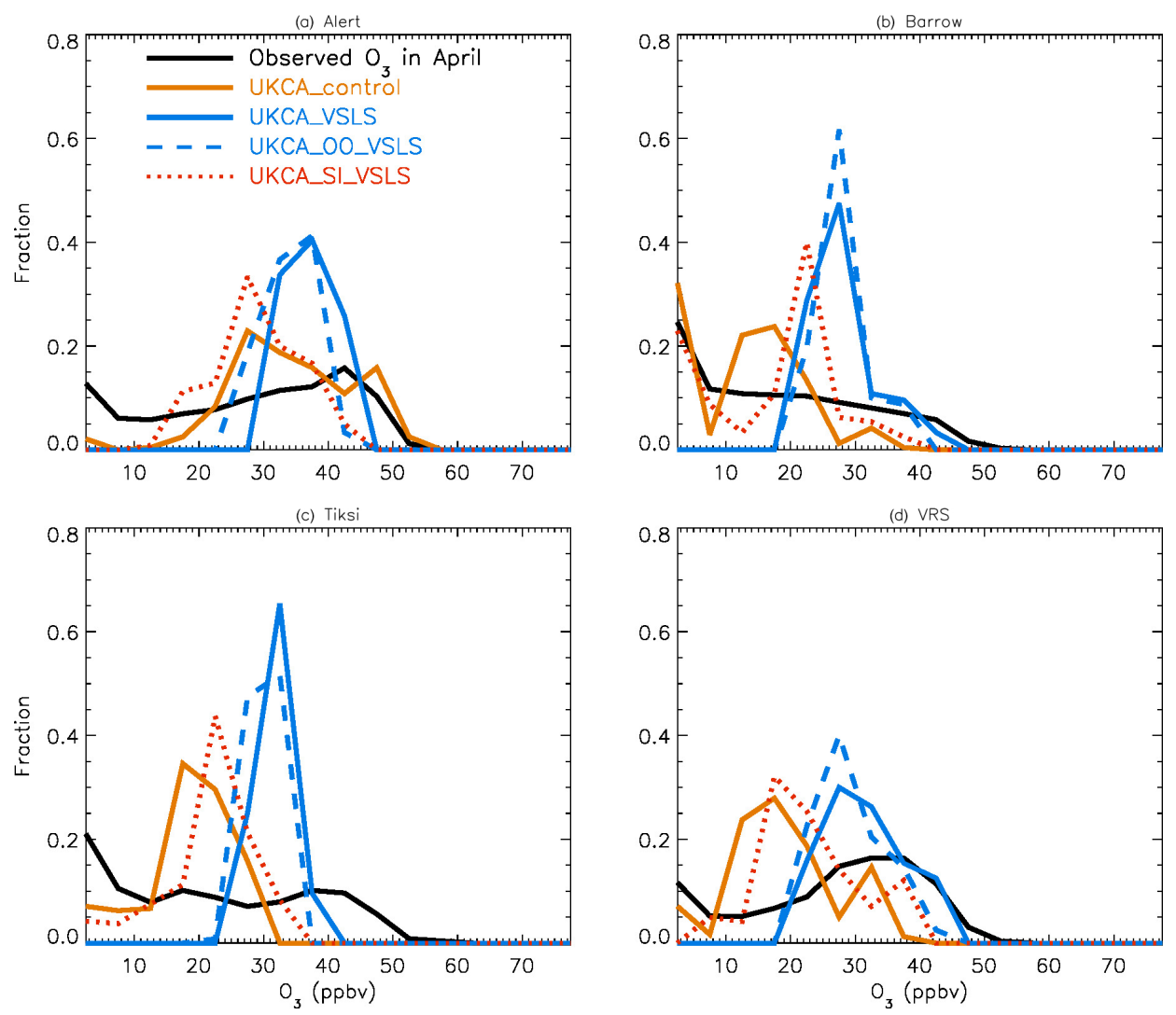

Figure 6. Same as Fig. 5 but for UKCA model results.

ferent correlation coefficients $R$ of $0.68(p<0.001)$ at Tiksi, $0.18(p<0.01)$ at Barrow, $0.47(p<0.001)$ at Summit, 0.62 $(p<0.001)$ at VRS, and $0.41(p<0.001)$ at Alert (Fig. 8).

Figures 7 and 8 show that large ODEs are mostly accompanied by enhanced $\mathrm{BrO}$. Statistical analysis shows (for the p-TOMCAT result only) that surface $\mathrm{BrO}$ simulated is negatively correlated with observed ozone at Tiksi, Summit, and VRS, with $R$ of $-0.49(p<0.001),-0.19(p<0.001)$, and $-0.51(p<0.001)$, respectively (Table 4 , column 3 ), while at Barrow and Alert, the correlation is not significant (with $R$ of $\sim-0.05$ ). However, the correlation between observed surface ozone and simulated tropospheric BrO column becomes significant with $R$ of $\sim-0.2(p<0.001$; Table 4, column 4) at these two sites; a similar phenomenon is seen between observed ozone and GOME-2 $\mathrm{BrO}_{\text {trop }}$ at Tiksi, Barrow, and VRS (Table 4, column 5), though this correlation does not exist at Summit and Alert. In general, boundary layer ozone is influenced by column $\mathrm{BrO}$ in the low troposphere rather than by surface $\mathrm{BrO}$, though these two factors are largely correlated in modelling output (Table 4, column 8). For example, observed ozone at Barrow and Alert are significantly correlated with simulated tropospheric-column $\mathrm{BrO}$ but not surface $\mathrm{BrO}$. This is because ozone has a much longer lifetime than $\mathrm{BrO}$; thus through vertical mixing and/or air ventilation at the top of the boundary layer, ozone and
$\mathrm{BrO}$ in the free troposphere may influence surface ozone within the boundary layer. For a specific location, surface ozone may not always represent ozone levels in higher layers, as surface BrO. Therefore, ozone-sonde vertical-profile data may supply more information than surface data. Note that at extremely low ozone conditions (e.g. after a complete ozone consumption by halogen chemistry in a stable boundary layer), the negative correlation between $\mathrm{BrO}$ and ozone concentrations may not exist (Zhao et al., 2016). This is because under that condition, the photochemical equilibrium is shifted from $\mathrm{BrO}$ towards atomic $\mathrm{Br}$.

Figures 9 and 10 show time series of troposphericcolumn BrO from GOME-2 along with outputs from pTOMCAT_control (Fig. 9) and UKCA_control (Fig. 10). The GOME-2 $\mathrm{BrO}_{\text {trop }}$ data are tropospheric-vertical-column $\mathrm{BrO}$ for each site at the overpass time. In general, p-TOMCAT $\mathrm{BrO}_{\text {trop }}$ matches GOME-2 $\mathrm{BrO}_{\text {trop }}$ well, with a correlation coefficient $R=0.59(p<0.001)$ at Tiksi, $0.37(p<0.001)$ at Barrow, $0.33(p<0.001)$ at VRS, and $0.30(p<0.001)$ at Alert. The lowest correlation is seen at Summit, with $R=0.16(p<0.1)$, where the satellite column does not show significant day-to-day perturbation (Table 4, column 7; Fig. 9). In UKCA, a similar correlation is found, with $R=0.32(p<0.01)$ at Tiksi, $0.31(p<0.01)$ at Barrow, and $0.39(p<0.001)$ at VRS. However, at Summit and Alert the 
Table 4. Correlation coefficients $(R)$ at each site between various variables used in Figs. 6 and 7. Note that * indicates probability value $<0.1,{ }^{* *}<0.01$, and ${ }^{* * *}<0.001$. $\mathrm{BrO}_{\text {trop }}$ is tropospheric-column $\mathrm{BrO}$, and $\mathrm{BrO}_{\text {surface }}$ is surface $\mathrm{BrO}$.

\begin{tabular}{|c|c|c|c|c|c|c|c|}
\hline$R$ & $\begin{array}{r}\mathrm{Obs} \mathrm{O}_{3} \text { vs. } \\
\text { model surface } \mathrm{O}_{3}\end{array}$ & $\begin{array}{l}\mathrm{Obs} \mathrm{O}_{3} \text { vs. } \\
\text { model } \mathrm{BrO}_{\text {surface }}\end{array}$ & $\begin{array}{l}\text { Obs } \mathrm{O}_{3} \text { vs. } \\
\text { model } \mathrm{BrO}_{\text {trop }}\end{array}$ & $\begin{array}{r}\text { Obs } \mathrm{O}_{3} \text { vs. } \\
\text { GOME-2 } \mathrm{BrO}_{\text {trop }}\end{array}$ & $\begin{array}{l}\text { Model surface } \mathrm{O}_{3} \text { vs. } \\
\text { model } \mathrm{BrO}_{\text {surface }}\end{array}$ & $\begin{array}{l}\text { Model BrO } \mathrm{Brop}_{\text {trop. }} \\
\text { GOME-2 } \mathrm{BrO}_{\text {trop }}\end{array}$ & $\begin{array}{l}\text { Model } \mathrm{BrO}_{\text {trop vs. }} \\
\text { model } \mathrm{BrO}_{\text {surface }}\end{array}$ \\
\hline Ticksi & $0.68^{* * *}$ & $-0.49^{* * *}$ & $-0.53^{* * *}$ & $-0.62^{* * *}$ & $-0.78^{* * *}$ & $0.59^{* * *}$ & $0.96 * * *$ \\
\hline Barrow & $0.49^{* * *}$ & -0.04 & $-0.23^{* * *}$ & $-0.32^{* *}$ & $-0.42^{* * *}$ & $0.37 * * *$ & $0.87^{* * *}$ \\
\hline Summit & $0.63^{* * *}$ & $-0.19^{* * *}$ & 0.03 & 0.09 & 0.00 & $0.16^{*}$ & $0.42^{* * *}$ \\
\hline Villum & $0.76^{* * *}$ & $-0.51^{* * *}$ & $-0.34^{* * *}$ & $-0.42^{* * *}$ & $-0.50^{* * *}$ & $0.33^{* *}$ & $0.57^{* * *}$ \\
\hline Alert & $0.24^{* * *}$ & $-0.05^{*}$ & $-0.22^{* * *}$ & 0.03 & $-0.36^{* * *}$ & $0.30^{* *}$ & $0.59^{* * *}$ \\
\hline
\end{tabular}
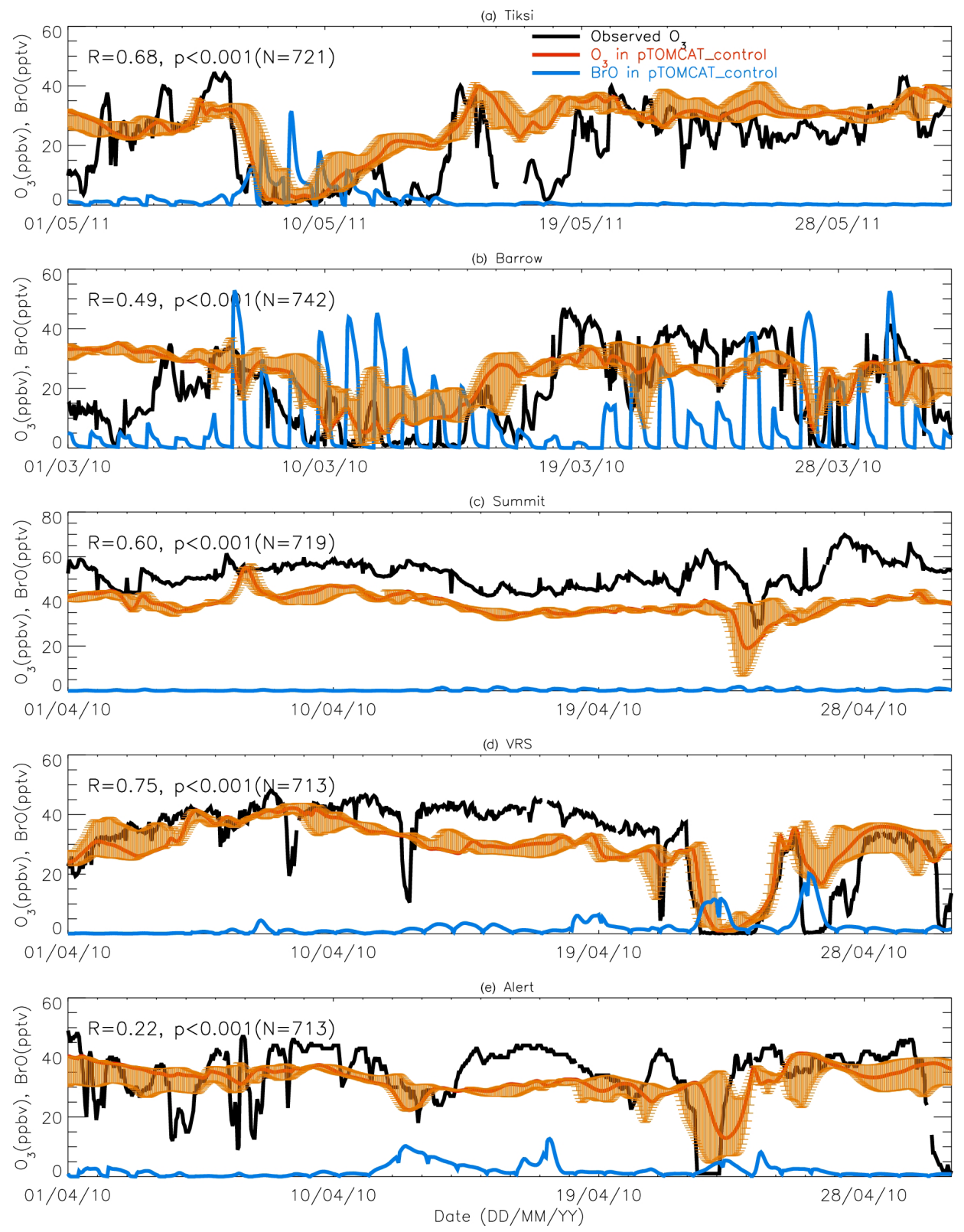

Figure 7. A 1-month-long time series of surface ozone and BrO at (a) Tiksi (May 2011), (b) Barrow (March 2010), (c) Summit (April 2010), (d) Villum (April 2010), and (e) Alert (April 2010). Observed ozone is shown in black, with pTOMCAT_control ozone shown in bold red, representing the value of the nearest central grid box to the observation site. The bold blue line is central grid box BrO. Note that maximum and minimum ozone, which are shown in orange bars, are taken from the five adjacent grid boxes next to the central grid box to highlight the possible range of the tracer concentrations. 

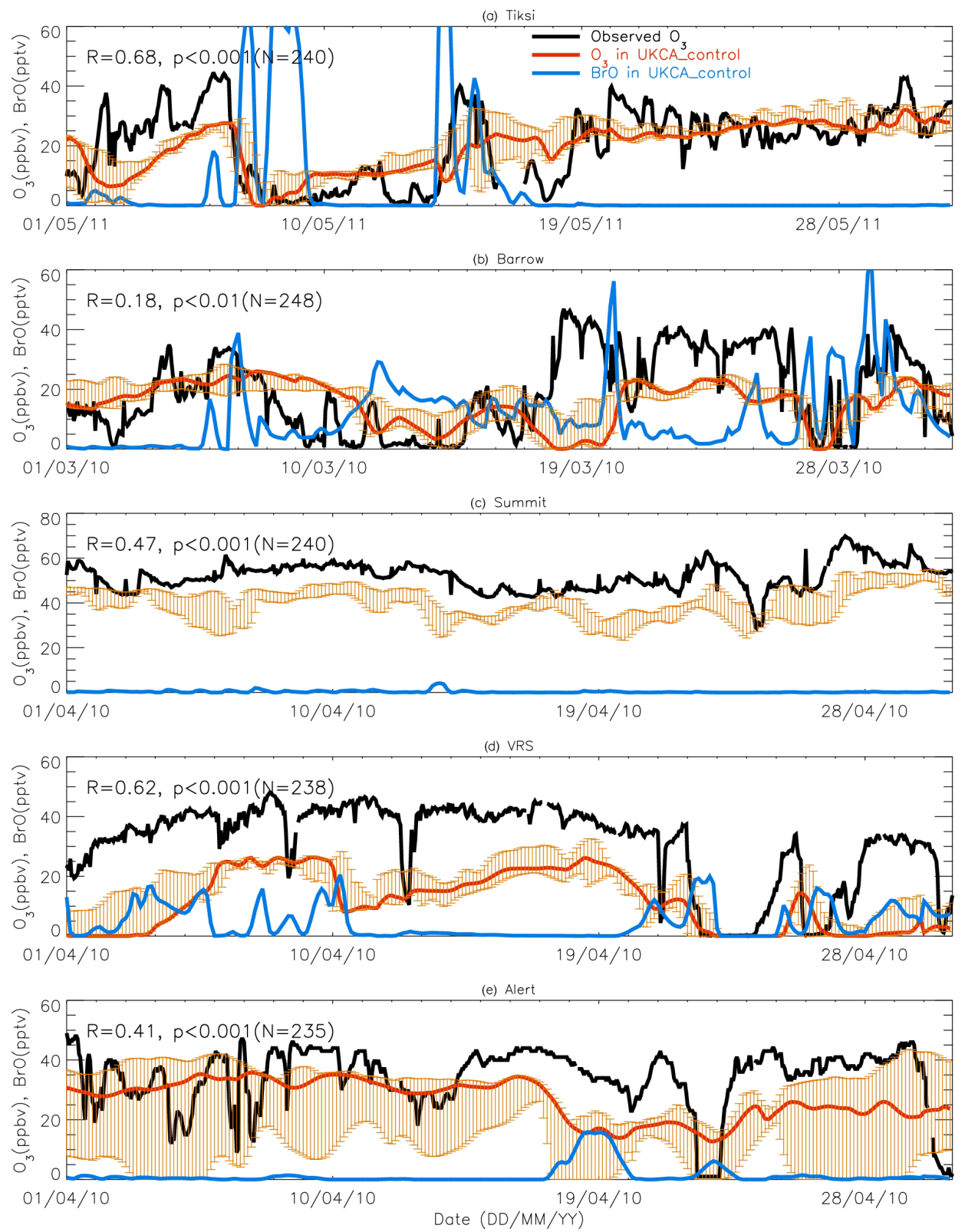

Figure 8. Same as Fig. 7 but for UKCA_control run results.

correlation coefficients are very small ( 0.05 at Summit and 0.1 at Alert). The p-TOMCAT model tends to overestimate satellite column $\mathrm{BrO}$ data by factors of $\sim 2$ during BEEs, e.g. during 7-11 May 2011 and during 9-15 March 2010, when there are large ODEs observed. But during non-ODE (or nonBEE) periods, modelled column $\mathrm{BrO}$ in p-TOMCAT is in good agreement with the GOME-2 data. In contrast, UKCA $\mathrm{BrO}_{\text {trop }}$ significantly underestimates during non-BEE periods, e.g. by a factor of $\sim 10$ over Summit, though it works well during BEEs. On average, UKCA $\mathrm{BrO}_{\text {trop }}$ is lower than the observation by $\sim 50 \%$.

\subsubsection{Vertical profiles}

A large ODE observed at Eureka between 3 and 7 April 2011 has been reported by Zhao et al. (2016), who pointed out that this ODE was a transported event associated with a strong cyclone originating in the Chukchi Sea on 31 March 2011. GOME-2 $\mathrm{BrO}_{\text {trop }}$ images (Fig. S5) clearly indicated a large spiral BrO plume over the Chukchi Sea on 1 April 2011 (Blechschmidt et al., 2016), which was transported across the Canadian high Arctic in the following days. This event might have influenced both Resolute and Alert, which are located within $\sim 500 \mathrm{~km}$ of Eureka. HYSPLIT $6 \mathrm{~d}$ back trajectories ending at 12:00 UTC on 5 April 2011 (Fig. 11) show that the 

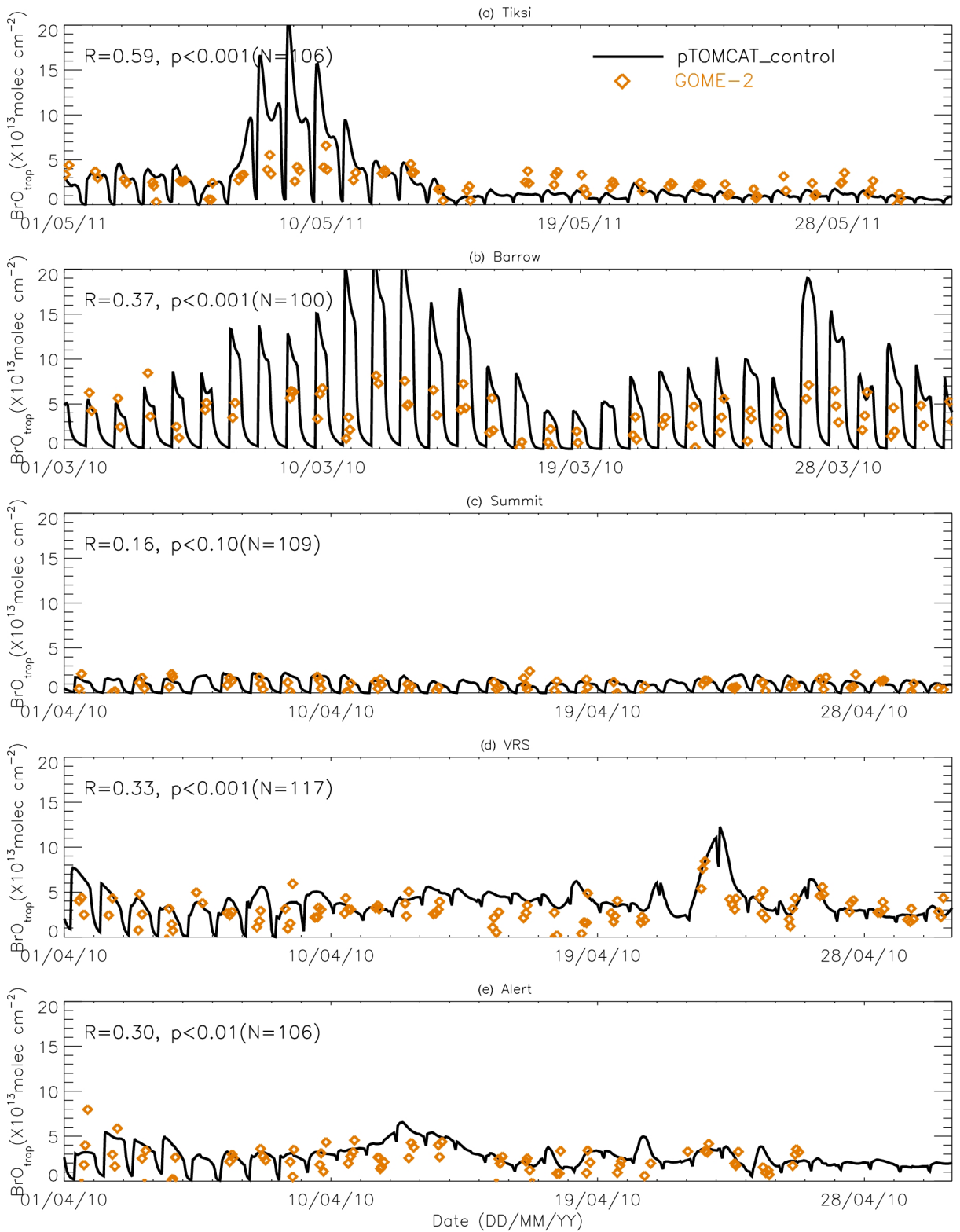

Figure 9. Time series of tropospheric BrO column from GOME-2 (orange diamond symbols) and pTOMCAT_control run BrO (black line). The correlation coefficient $R$ and statistical significance level $p$ at each site are given.

air mass history of the three sites has a very similar transport pattern, further indicating that these three sites were influenced by the same synoptic system. For this reason, we extend this case study by looking at ozone-sonde data from all three sites as shown in Figs. 12a-c and 13a-c. Ozonesonde data clearly indicate a severe ozone depletion layer at an altitude of $<2 \mathrm{~km}$ during 3-7 April 2011 at both Resolute and Eureka, with minimum ozone less than $1 \mathrm{ppbv}$ in the near-surface layer. At Alert, the ozone depletion strength was a bit weaker than at the other two sites, but the depleted ozone layer still reaches an altitude of $1-1.5 \mathrm{~km}$. Moreover, the most severe ozone depletion at Alert on 4 April is not near the surface but rather at an elevated height of 500 $800 \mathrm{~m}$. The simulated ozone profiles in the UKCA_control run (Fig. 12d-f) generally match the ozone-sonde profiles in the $0-4 \mathrm{~km}$ range. For this ODE, both the timing of occurrence and height range of the ODE are roughly captured by the UKCA model. The modelled $\mathrm{BrO}$ profile is shown in Fig. $12 \mathrm{~g}-\mathrm{i}$, with enhanced $\mathrm{BrO}$ being simulated in association with ozone depletion. At Eureka, the simulated maximum surface $\mathrm{BrO}$ is similar to the MAX-DOAS measurement, with a maximum VMR of $\sim 20 \mathrm{pptv}$ for this event (Zhao et al., 2016, 2017). In the pTOMCAT_control run, ozone-poor air is not limited to the near-surface layer (or 

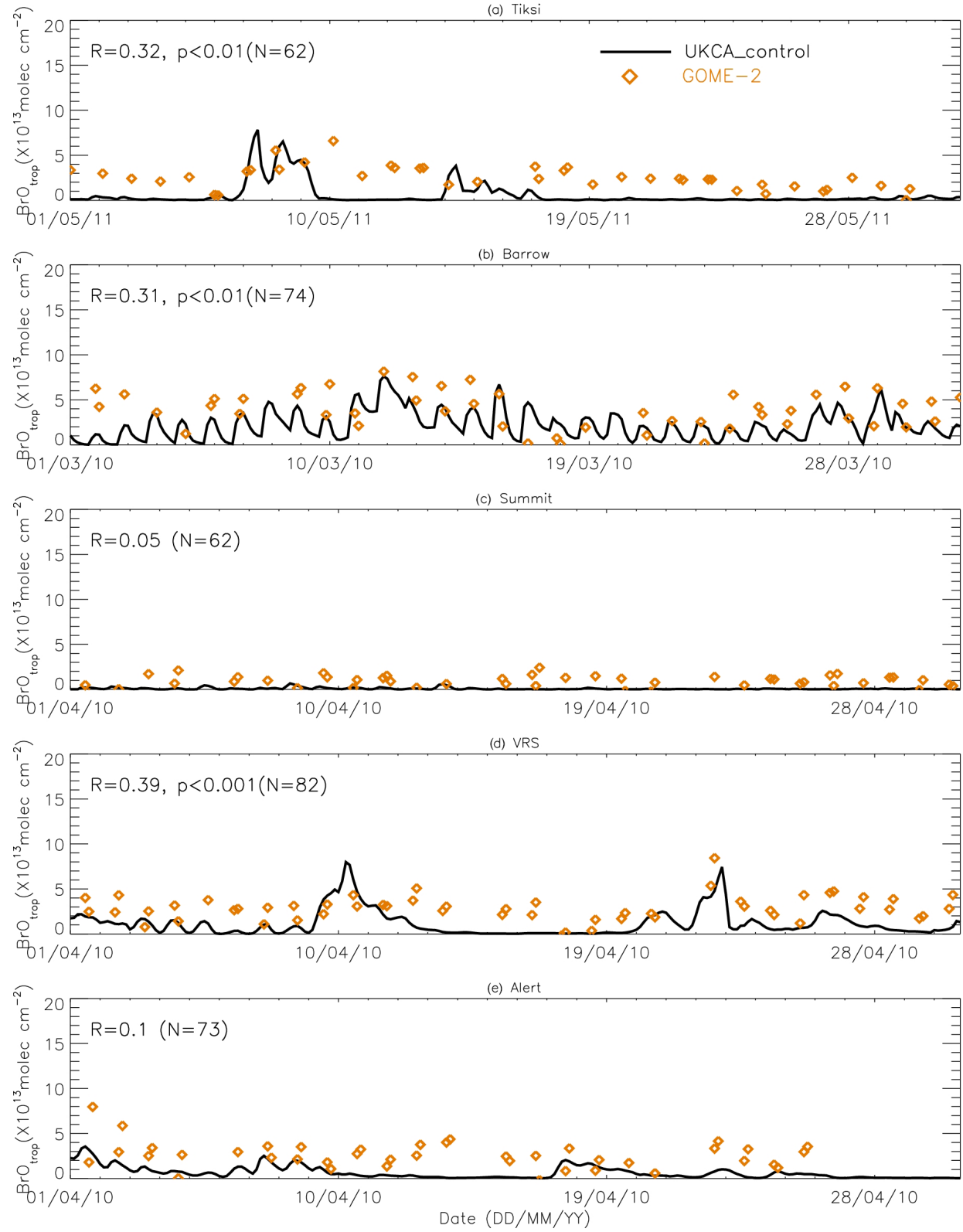

Figure 10. Same as Fig. 9 but for UKCA_control run results.

$<1.5 \mathrm{~km}$ ), but rather depleted ozone is well spread over the lower troposphere to a height of $\sim 4 \mathrm{~km}$ (Fig. 13d-f). Similarly, simulated $\mathrm{BrO}$ in p-TOMCAT is also uniformly spread in the lower troposphere (Fig. 13g-i). A zoom-in comparison between the GOME-2 tropospheric-column $\mathrm{BrO}$ and modelintegrated $\mathrm{BrO}$ for the period of 1-10 April 2011 is shown in Fig. 14 (for UKCA) and Fig. 15 (for p-TOMCAT). Satellite BrO columns reached a peak first on 3 April 2011 at Resolute. After $1 \mathrm{~d}$, the peak appeared at Eureka and Alert. The UKCA_control run shows a similar transport pattern of enhanced $\mathrm{BrO}$, which reached Resolute first, and then Eureka and Alert (Fig. 14). However, the pTOMCAT_control run shows enhanced $\mathrm{BrO}$ reaches Eureka and Resolute first and then Alert later (Fig. 15). The differences are likely related to the different model resolutions and grid box coordinate. The above finding is consistent with our previous conclusion made in Zhao et al. (2016) that this ODE is transported associated with a large cyclone.

A strong correlation between the modelled $\mathrm{BrO}_{\text {trop }}$ and the GOME-2 $\mathrm{BrO}_{\text {trop }}$ data can be seen at Resolute, with a high $R$ of $0.71(p<0.001)$ in UKCA (Fig. 14d) and 0.59 $(p<0.001)$ in p-TOMCAT (Fig. 15d). At the other two sites, the correlation is positive in UKCA but with small $R$ of $\sim 0.2$; in p-TOMCAT, the $R$ is small to medium: 0.45 at 
NOAA HYSPLIT MODEL

Backward trajectories ending at 12:00 UTC 05 Apr 11

GHDA Meteorological Data

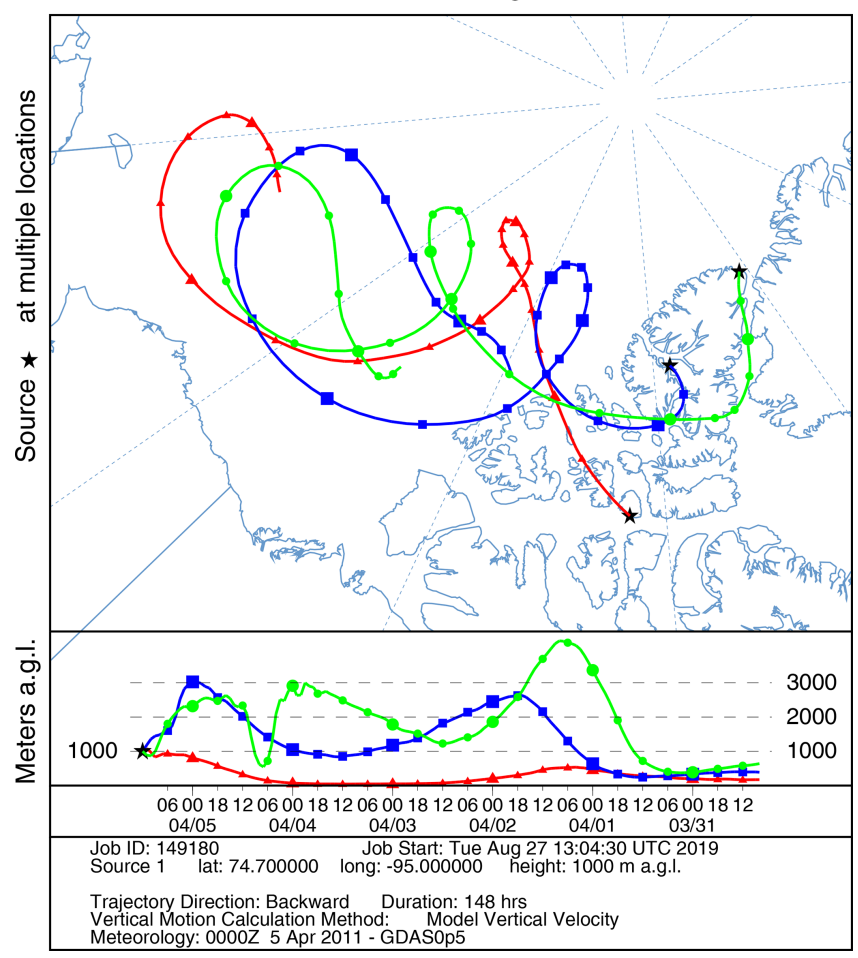

Figure 11. HYSPLIT $6 \mathrm{~d}$ back trajectories for Resolute, Eureka, and Alert ending at 12:00 UTC on 5 April 2011.

Eureka $(p<0.01)$ and $0.33(p<0.05)$ at Alert. The UKCA $\mathrm{BrO}_{\text {trop }}$ is on average lower than the satellite data by $\sim 50 \%$ (refers to the regression equations shown in Fig. 14), which is opposite to the overestimated $\mathrm{BrO}_{\text {trop }}$ by $50 \%-90 \%$ in the p-TOMCAT model (in Fig. 15). This difference is in line with the differences discussed above in total $\mathrm{Br}_{Y}$ between the two models (in Sect. 4.1), although the same total bromine emissions are applied.

\section{Discussions}

Regarding tropospheric total $\mathrm{Br}_{Y}$ in the Arctic, as mentioned previously, the model-to-model difference can be as large as $100 \%$ in the near-surface layer (under the same bromine loading). As a consequence, the ozone loss due to bromine chemistry can be different by a factor of 2 . The relatively high $\mathrm{Br}_{Y}$ in the pTOMCAT_control run is partly due to the higher $\mathrm{BrO}$ partitioning in p-TOMCAT (attributed to the inclusion of heterogeneous reactions on cloud droplets) - and thus less wet removal of soluble bromine species - and partly due to stronger vertical mixing of air masses in the lower troposphere and thus less dry-deposition removal of reactivebromine species from the surface layer.
On a global scale, the uncertainty in the sea spray (from open ocean) source can be a factor of 4 (Lewis and Schwartz, 2004). On sea ice, the blowing-snow-related SSA production is sensitive to both snow salinity and bulk sublimation flux calculated (as a complex function of near-surface wind speed, temperature, and relative humidity, etc.; Yang et al., 2019). Although we lack snow data on Arctic sea ice to strictly constrain the snow salinity used for the Arctic that is 3.5 times that of the Antarctic Weddell Sea (Sect. 3.1), the likelihood of higher snow salinity in the Arctic implies that there is more SSA generated from same amount of blowingsnow sublimation flux (also with slightly larger SSA in size). As a consequence, there is more reactive bromine released from blowing snow in the Arctic than in the Antarctic. Given that the snow salinity effect on SSA mass production is almost linear, the uncertainty caused by this factor can be estimated when more snow data in the Arctic are available. However, in terms of relative bromine release from SSA, the actual emission flux varies and depends on the salinity; this is due to the cut-off threshold size applied (i.e. a dry $\mathrm{NaCl}$ radius of $10 \mu \mathrm{m}$ in the control run). Therefore, the reactivebromine release from SSA is a function of snow salinity and SSA spectrum.

Another factor that may directly affect reactive-bromine emission is the depletion factor. Figure S6 shows simulated ozone from the pTOMCAT_Fixed_DF run, in which a fixed bromine DF scheme (Table S1) is used. For comparison, the pTOMCAT_control run result is shown, in which the seasonal DF scheme (Table 1) is applied. As can be seen, the timing of the spring ozone minimum shifts slightly from April in pTOMCAT_control towards March in pTOMCAT_Fixed_DF, which makes the model agreement poorer as the observed ozone minimum is in May at the four coastal sites. To achieve better agreement with the observations, the model needs either an even larger seasonal amplitude of bromine DF than that in Table 1 or a further shift in the DF phase by at least 1 month, e.g. to allow the annual maximum DF (=0.53) to shift from May to June. However, due to lack of year-round SSA bromide data in the Arctic, we could not validate the DF patterns used in this study as this requires systematic measurements of the SSA bromide depletion strength in the Arctic. This is critical as local SSA is a large source of bromine, and the seasonal DF affects not only the timing but also the total bromine flux to the atmosphere. Model bias also comes from applying the same depletion factor scheme (i.e. Table 1) to both open-ocean-sourced sea spray and sea-ice-sourced SSA. As we know, freshly released sea spray is alkaline with $\mathrm{pH}>8$, and therefore the anions in sea spray may buffer the absorbed nitrate and sulphate before getting acidified to allow bromide to be released through heterogeneous reaction, e.g. $\mathrm{HOBr}+\mathrm{Br}^{-} \rightarrow \mathrm{Br}_{2}$ (e.g. Sander et al., 2003; Breider et al., 2009). On sea ice, the situation could be different as surface snow may have been pre-acidified before grains are lifted into the air to form SSA. Unfortunately, this difference in the process of bromide lib- 

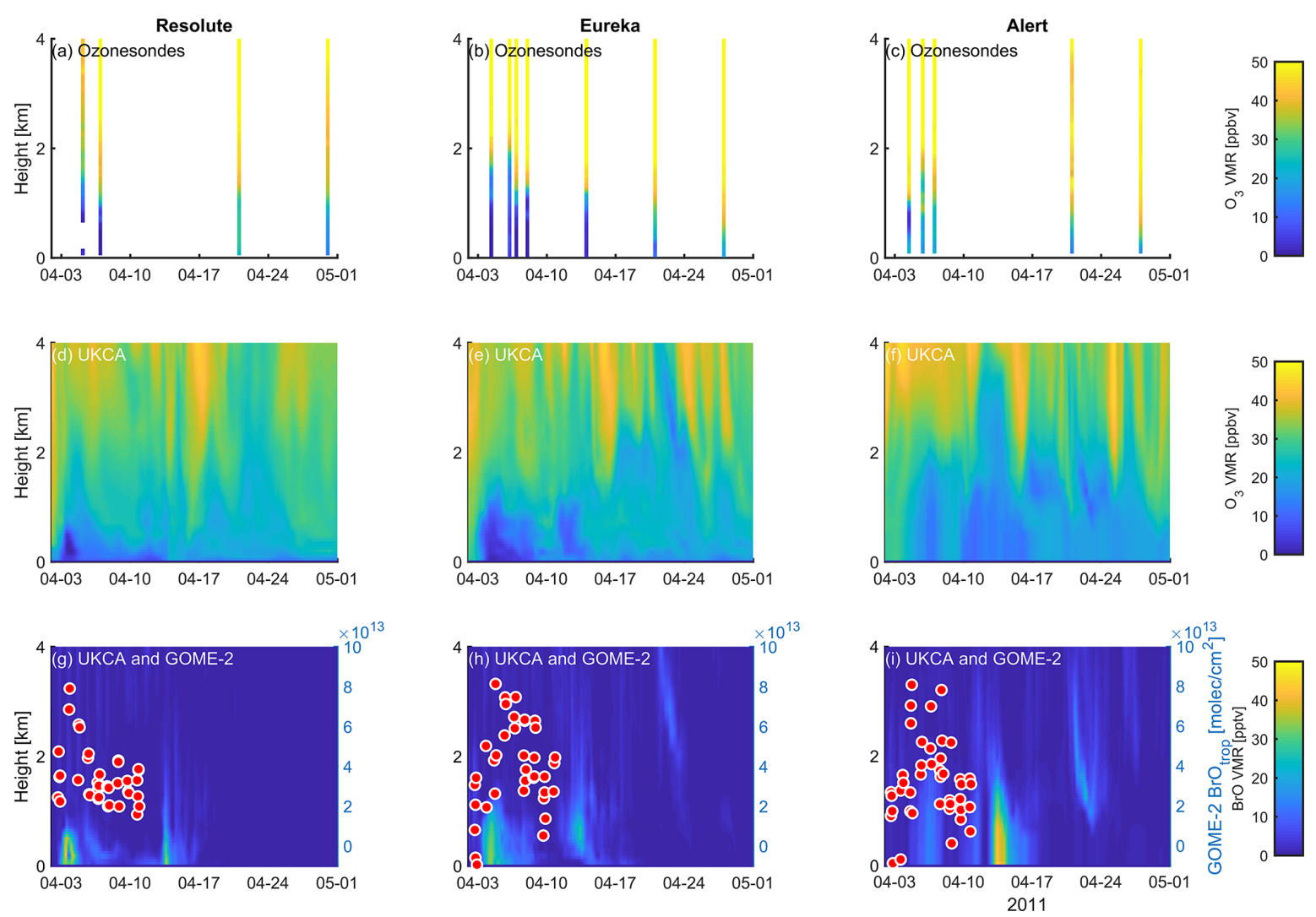

Figure 12. Profile of ozone-sonde (0-4 km) at Resolute (a), Eureka (b), and Alert (c) during April 2011. UKCA_control ozone profiles (d-f) and $\mathrm{BrO}$ profiles (g-i) are also plotted. GOME-2 overpass data (tropospheric-column BrO) of the period 1-10 April 2011 are also plotted in (g)-(i) and detailed in Fig. 10.

eration from SSA particles is beyond the scope of this study, but we note that it could result in bias, e.g. in bromide releasing from airborne SSA in strength, timing, and locations.

To investigate model sensitivity to the above key parameters used in describing sea-ice-sourced SSA and reactivebromine release from SSA, we performed additional model experiments (in Table 3) by altering one or a few parameters in each experiment and comparing the output with the pTOMCAT_control output (for the year 2007). For most key parameters, we designed a pair run with one applying a higher value and the other a lower value than in the control run. Model results are shown in Fig. 16, with derived seaice-sourced $\operatorname{Br}_{Y}$ (April) and ozone (as well as change with respect to the control run) shown in Table 3.

Since the control run applied a salinity that is 3.5 times that in the Weddell Sea, the runs with 10 times the salinity in pTOMCAT_high_salinity and 1 times the salinity in pTOMCAT_low_salinity are roughly $\sim 3$ times and approximately one-third of the control run salinity, respectively. Comparing to the pTOMCAT_control run, the sea-ice-sourced $\mathrm{Br}_{Y}$ (April) in pTOMCAT_high_salinity increases by $+94.8 \%$, corresponding to additional ozone loss by $-37.5 \%$. Sea-icesourced $\mathrm{Br}_{Y}$ (April) in pTOMCAT_low_salinity decreases by $-60 \%$, corresponding to ozone increase by $+61 \%$. It is interesting to note that the ozone and $\operatorname{Br}_{Y}$ percentage change (in absolute value) in pTOMCAT_low_salinity is at a ratio of $1: 1$, but in the pTOMCAT_high_salinity run the ozone percentage change is only less than half of the $\mathrm{Br}_{Y}$ percentage change. sea-ice-sourced $\mathrm{Br}_{Y}$ in pTOMCAT_SSA20 $\mu \mathrm{m}$ (with a large cut-off radius size of $20 \mu \mathrm{m}$ ) increases by $+42.3 \%$, corresponding to additional ozone loss by $-21.1 \%$, which is almost half of the $\operatorname{Br}_{Y}$ percentage change. In contrast, sea-ice-sourced $\mathrm{Br}_{Y}$ in pTOMCAT_SSA5 $\mu \mathrm{m}$ (with a small cut-off radius size of $5 \mu \mathrm{m}$ ) decreases by $-55.1 \%$, corresponding to ozone increase by $+45.4 \%$. Sea-ice-sourced $\mathrm{Br}_{Y}$ in pTOMCAT_ $2 \times \mathrm{DF}$ (a doubled DF) increases by $84.5 \%$, corresponding to additional ozone loss by $-35.7 \%$ (less than half of the $\mathrm{Br}_{Y}$ change). Sea-ice-sourced $\mathrm{Br}_{Y}$ in pTOMCAT_0.5 $\times$ DF (a halved DF) decreases by $-47.3 \%$, corresponding to additional increase by $+45.8 \%$ (almost the same amount as the $\operatorname{Br}_{Y}$ change). Sea-ice-sourced $\operatorname{Br}_{Y}$ in pTOMCAT_spectrum_1 (with a small $N=10$ ) reduces by $-20.1 \%$, corresponding to ozone increase by $+16.5 \%$. Sea-ice-sourced $\operatorname{Br}_{Y}$ in pTOMCAT_spectrum_2 reduces by $-42.2 \%$, corresponding to ozone gain by $+38.6 \%$. In all model experiments with reduced $\mathrm{Br}_{Y}$ from sea ice, the per- 

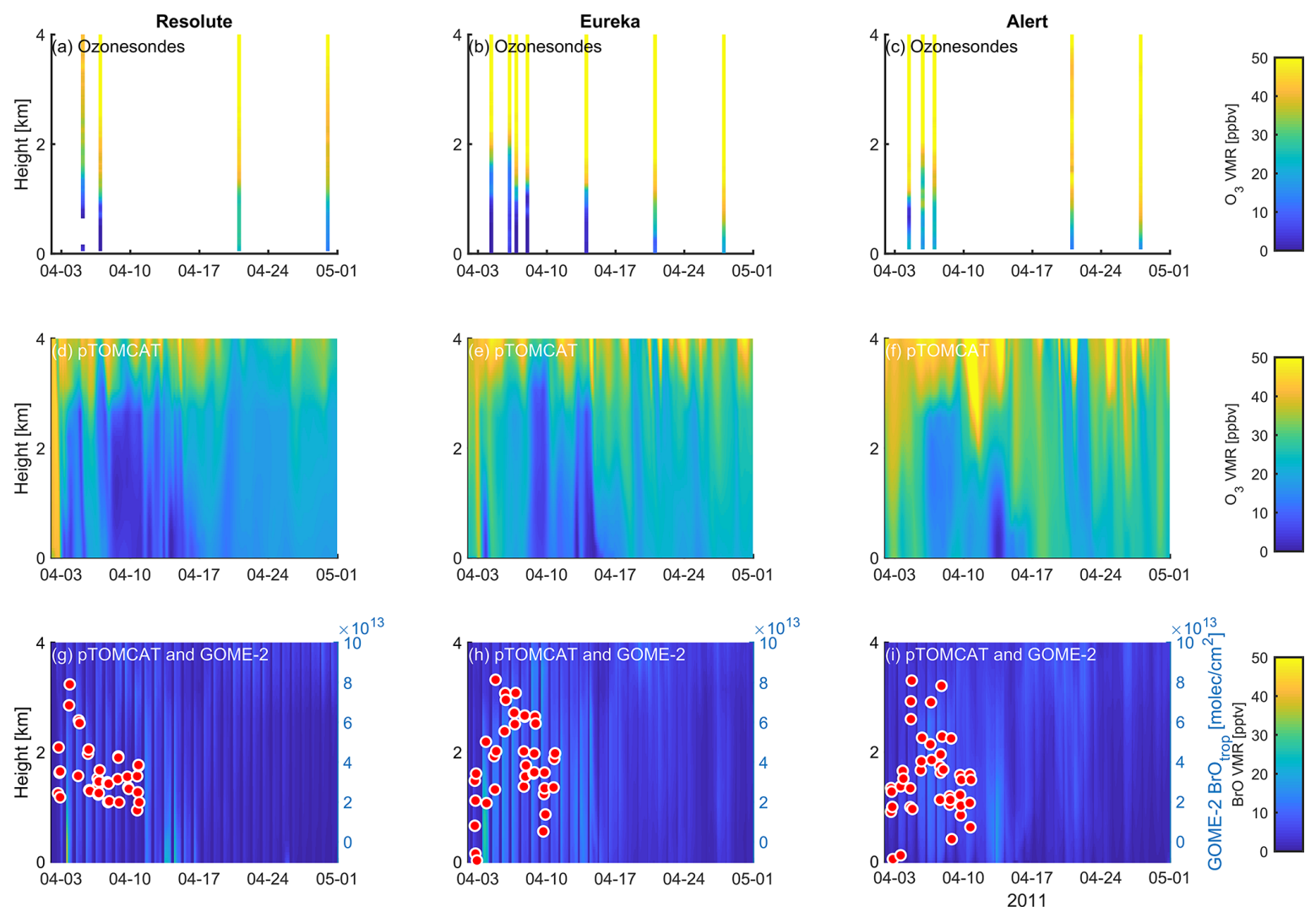

Figure 13. Same as Fig. 12 but for pTOMCAT_control run results.

centage change in ozone is almost the same amount as $\mathrm{Br}_{Y}$ change. However, in the $\mathrm{Br}_{Y}$ increasing cases, the ozone percentage (loss) change is only half or less than that of the $\mathrm{Br}_{Y}$ percentage change, indicating that ozone consumption efficiency is getting lower at higher reactive-bromine loading; therefore, introducing extra reactive bromine to the environment will not necessary result in an equivalent amount of ozone loss as at low reactive-bromine loading.

The above model experiments clearly show the possible range of modelled ozone and $\mathrm{Br}_{Y}$ in the Arctic caused by uncertainty in each key parameter involved in the parameterizations. From these runs we can derive the likely maximum effect from the sea-ice-sourced SSA from blowing snow. For example, the mean DF values in spring (March, April, and May; see Table 1) are $~ 0.5$, and a doubling DF indicates that all bromide in SSA is released to the air; thus the pTOMCAT_ $2 \times$ DF run represents an extreme scenario with the maximum effect from blowing snow (with other conditions unchanged), so as the pTOMCAT_SSA20 $\mu \mathrm{m}$ run is under this cut-off threshold, almost all SSA formed from blowing snow releases bromide as a source of reactive bromine. The pTOMCAT_high_salinity represents another extreme case that shows the large effect from blowing snow. Their combination effect can be multiplied and result in an even larger effect. Equivalently, under extremely low snow salin- ity (such as in pTOMCAT_low_salinty) or small DF (such as in pTOMCAT_ $0.5 \times \mathrm{DF}$ ), the blowing-snow-sourced SSA effect on Arctic surface ozone and reactive bromine will be less important than the control run. Therefore, we require further field measurement to collect data to constrain these key model parameters.

\section{Summary}

For the first time, using two global chemistry models, we have examined the three tropospheric-bromine sources (bromocarbons, open-ocean sea spray and sea-ice-sourced SSA) and their impacts on Arctic boundary layer bromine and ozone loss. Our modelling experiments show that inclusion of bromine chemistry can greatly improve Arctic surface ozone seasonality reproduction, in particular the spring ozone depletion observed at most Arctic coastal sites, such as Tiksi, Barrow, VRS, and Alert. However, inclusion of halogen-chemistry leads to severe underestimation of spring ozone at inland sites such as Summit and Pallas. Our model results show that the contribution of very-short-lived bromocarbons to Arctic tropospheric $\mathrm{Br}_{Y}$ is less than $0.5 \mathrm{pptv}$ in the near-surface layer, corresponding to small ozone loss of $<1$ ppbv. Multi-year simulations show that inclusion of bromine chemistry can cause Arctic surface ozone loss by 

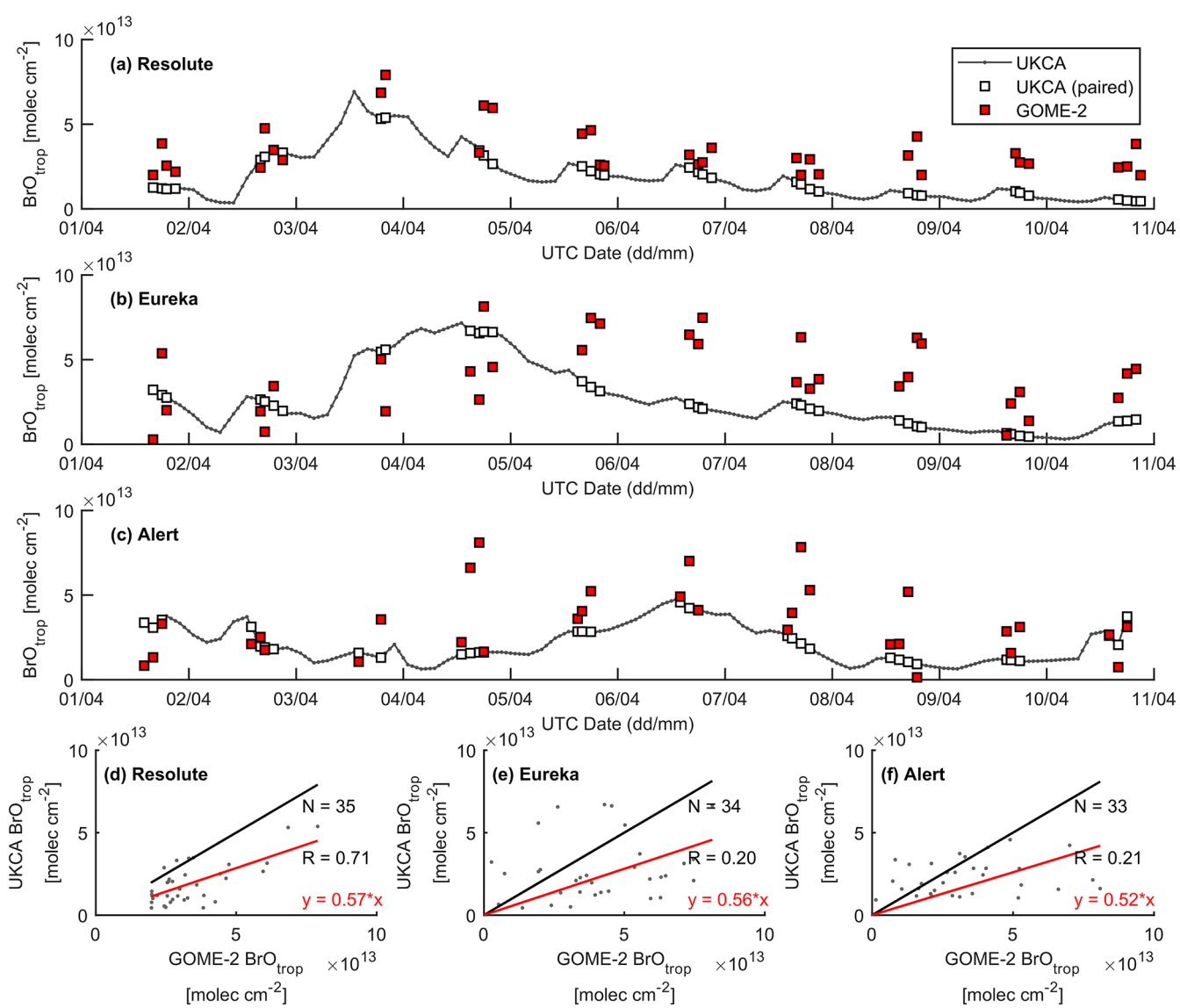

Figure 14. Time series of GOME-2 and UKCA_control tropospheric BrO column at (a) Resolute, (b) Eureka, and (c) Alert for the period 1-10 April 2011. Correlation plots between the model and GOME-2 are shown in (d)-(f), with the black line representing a $1: 1$ plot and the red line representing the regression fit.

10-20 ppbv in spring, with almost half of the ozone loss attributed to open-ocean-sourced SSA and the other half from sea-ice-sourced SSA. However, without SI-sourced bromine, models cannot reproduce Arctic ozone depletion events, and OO-sourced bromine only affects background atmospheric ozone and cannot by itself produce any polar surface ODEs.

Although a very similar tropospheric-halogen scheme was applied in the two models, the model-to-model differences are relatively large. For example, boundary layer $\mathrm{Br}_{Y}$ in the p-TOMCAT control run is higher than in the UKCA control run, which is likely related to the different wet and dry depositions of reactive-bromine species. Comparing the GOME2 satellite data, p-TOMCAT $\mathrm{BrO}_{\text {trop }}$ overestimates the observations by a factor of $\sim 2$ during BEEs but agrees well with the observations during non-BEEs. In contrast, UKCA $\mathrm{BrO}_{\text {trop }}$ generally underestimates the observations by $\sim 50 \%$ during BEEs but severely underestimates the observation during non-BEEs (e.g. more than an order of magnitude at Summit). Despite the model differences, both models' outputs of time series of surface ozone and tropospheric-column $\mathrm{BrO}$ (in spring) show significant correlation to the observa- tions at most selected periods, which strongly supports the physical and chemical mechanisms implemented.

Due to the relatively coarse model resolution (e.g. $2-3^{\circ}$ in the horizontal direction), our models cannot resolve smallscale ODEs, e.g. with a spatial scale $<\sim 500 \mathrm{~km}$ (or with a temporal scale of $<\sim 1 \mathrm{~d}$ ). Thus, to allow a better reproduction of small-scale ozone events, a fine-resolution model is needed. Ozone-sonde data from three adjacent high Arctic Canadian sites (Resolute, Eureka, and Alert), satellite $\mathrm{BrO}_{\text {trop }}$, and back-trajectory model output clearly indicate a large ODE (and BEE) in association with a stormy system, the event of which is successfully captured by the two models, further confirming that ODEs and BEEs can be transported over long distances. Although our global models cannot be able to reproduce small-scale ODEs, the success of the models in capturing large-scale ODEs (and BEEs) gives additional evidence from a chemistry side to the proposed mechanism of SSA production and reactive-bromine release from blowing snow on sea ice (Yang et al., 2008, 2019; Frey et al., 2020). Note that the success of the blowingsnow mechanism does not necessarily rule out other possibilities, including the proposed candidates of reactive bromine 

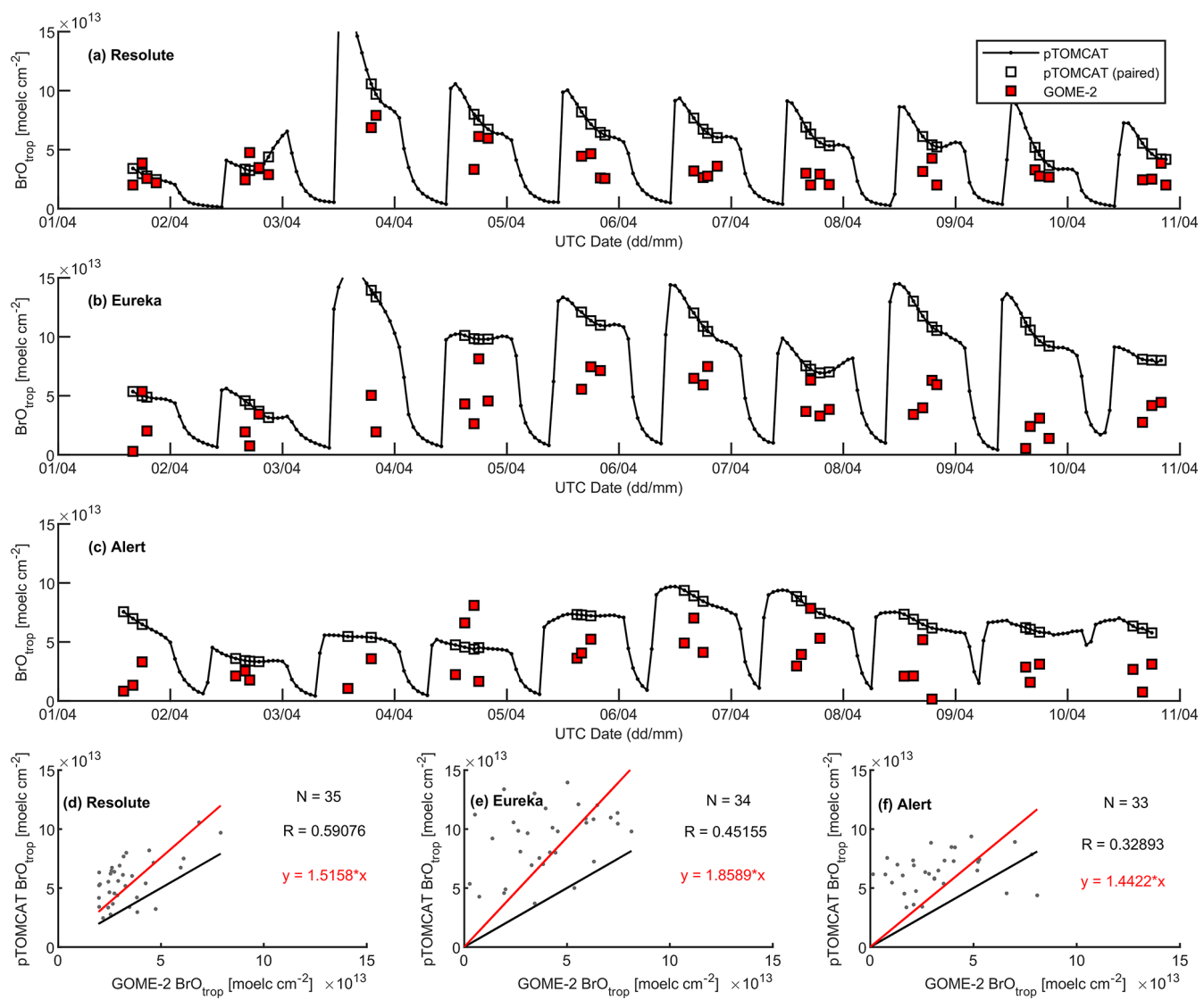

Figure 15. Same as Fig. 14 but for pTOMCAT_control run results.

from snowpack, open leads, frost flowers, sea ice surface, etc. Change in sea ice extent and type in a warming climate will influence Arctic boundary layer chemistry and Arctic climate, including the deposition of atmospheric mercury to the surface (Wang et al., 2019).

Data availability. The Arctic surface ozone data were retrieved from the World Data Centre for Reactive Gases (WDCRG) and archived at the NOAA Global Monitoring Laboratory (https://www.ncei.noaa.gov/access/metadata/landing-page/ bin/iso?id=gov.noaa.nodc:0220862, McClure-Begley et al., 2020). The ozone-sounding data were archived at the World Ozone and Ultraviolet Radiation Data Centre (WOUDC). The NOAA Air Resources Laboratory (ARL) HYSPLIT model outputs can be accessed from their website (https://www.ready.noaa.gov/HYSPLIT. php, NOAA, 2020). For GOME-2 tropospheric-BrO-column data, contact the corresponding authors Anne-M. Blechschmidt and Andreas Richter. For modelling outputs from UKCA and p-TOMCAT, contact Xin Yang.

Supplement. The supplement related to this article is available online at: https://doi.org/10.5194/acp-20-15937-2020-supplement.
Author contributions. XY designed the study, performed model experiments, and interpreted model output. AuMB provided surface ozone data, and DT provided ozone-sonde data of the three Canadian sites. KB, KS, and XZ provided MAX-DOAS BrO data at Eureka; AnMB and AR provided GOME-2 tropospheric columns of $\mathrm{BrO}$, and $\mathrm{XZ}$ contributed to GOME-2 and ozone-sonde data analysis. XY prepared the draft of the paper with contributions from all co-authors in both data interpretation and discussions.

Competing interests. The authors declare that they have no conflict of interest.

Acknowledgements. We thank the IASOA (https://www.iasoa.org, last access: 1 December 2020) trace gases working group for stimulating and encouraging this investigation. We thank the many observers who obtained these data over many years of careful work. Ozone-sounding data and surface data for Alert were provided by Environment and Climate Change Canada (ECCC). DANCEA is acknowledged for the financial support to carry out ozone measurements at Villum Research Station. The Eureka MAX-DOAS $\mathrm{BrO}$ measurements were made at the Polar Environment Atmospheric Research Laboratory (PEARL) by the Canadian Network for the Detection of Atmospheric Change (CANDAC), primarily supported by NSERC, CSA, and ECCC. Ozone measurements 

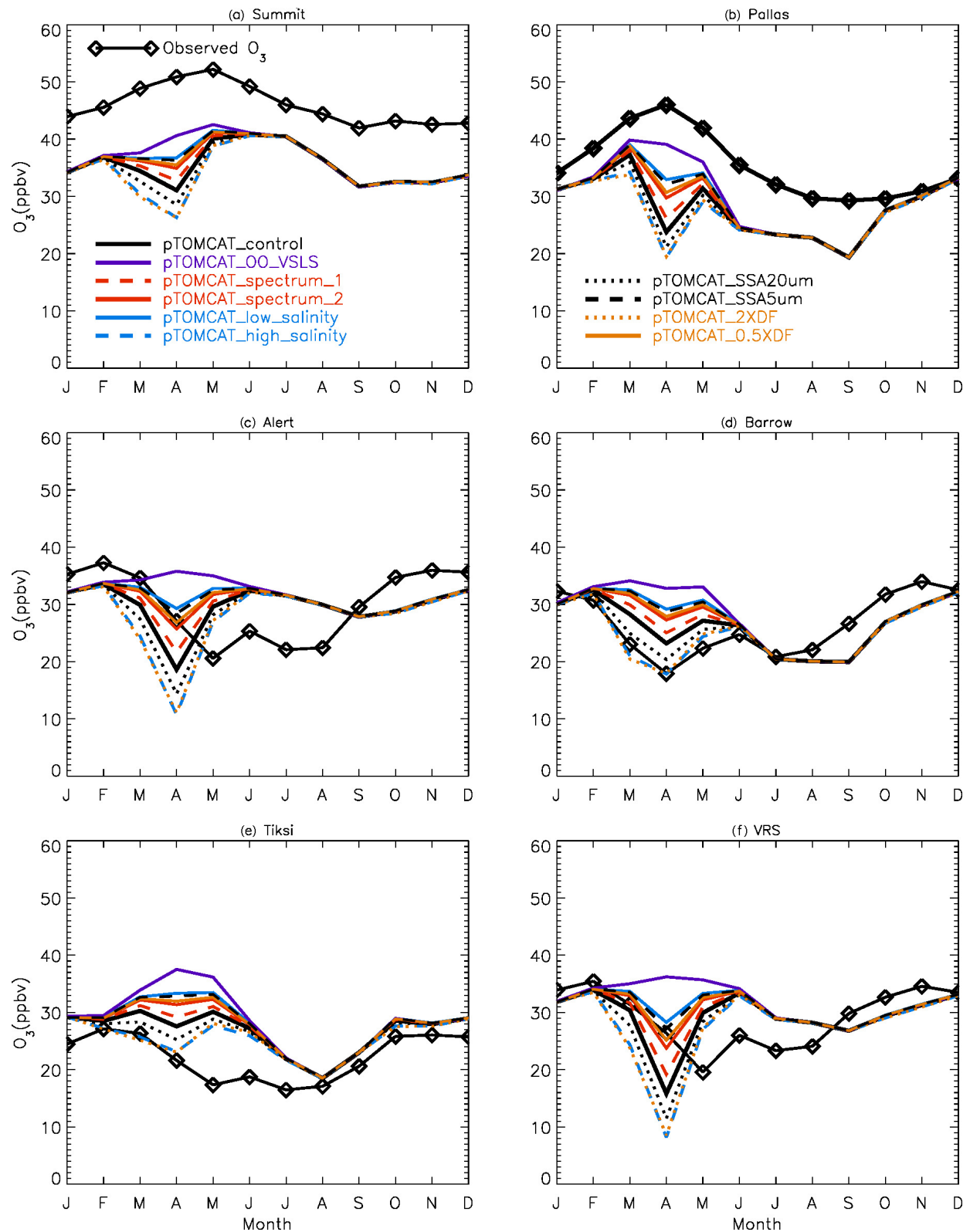

Figure 16. Monthly mean ozone at the six sites in the Arctic. Ozone observations are climatology, and simulated ozone outputs are only for the year 2007.

from the Tiksi Observatory are supported by the Russian Federal Service for Hydrological and Meteorological Monitoring (Roshydromet) and the Russian Arctic and Antarctic Research Institute (AARI). The NOAA Arctic Research Program has contributed to establishing surface ozone measurement programs in Tiksi and Eureka. The Summit and Barrow surface ozone observations are collected by the NOAA Global Monitoring Laboratory. The Pallas surface ozone observations are collected by the Finnish Meteorological Institute. The authors gratefully acknowledge the NOAA Air Resources Laboratory (ARL) for the provision of the HYSPLIT transport and dispersion model and/or the READY website (http://www.ready.noaa.gov, last access: 1 December 2020) used in this publication.
Financial support. Anne-M. Blechschmidt and Andreas Richter gratefully acknowledge the funding by the Deutsche Forschungsgemeinschaft (DFG, German Research Foundation; project no. 268020496-TRR 172), within the Transregional Collaborative Research Center "ArctiC Amplification: Climate Relevant Atmospheric and SurfaCe Processes, and Feedback Mechanisms (AC) ${ }^{3}$, in subproject $\mathrm{C} 03$.

Review statement. This paper was edited by Dwayne Heard and reviewed by two anonymous referees. 


\section{References}

Abbatt, J. P. D., Thomas, J. L., Abrahamsson, K., Boxe, C., Granfors, A., Jones, A. E., King, M. D., Saiz-Lopez, A., Shepson, P. B., Sodeau, J., Toohey, D. W., Toubin, C., von Glasow, R., Wren, S. N., and Yang, X.: Halogen activation via interactions with environmental ice and snow in the polar lower troposphere and other regions, Atmos. Chem. Phys., 12, 6237-6271, https://doi.org/10.5194/acp-12-6237-2012, 2012.

Adler, R. F., Huffman, G. J., Chang, A., Ferraro, R., Xie, P.-P., Janowiak, J., Rudolf, B., Schneider, U., Curtis, S., Bolvin, D., Gruber, A., Susskind, J., Arkin, P., and Nelkin, E.: The Version-2 Global Precipitation Climatology Project (GPCP) Monthly Precipitation Analysis (1979-Present), J. Hydrometeorol., 4, 1147-1167, https://doi.org/10.1175/15257541(2003)004<1147:TVGPCP>2.0.CO;2, 2003.

Afe, O. T., Richter, A., Sierk, B., Wittrock, F., and Burrows, J. P.: BrO emission from volcanoes: A survey using GOME and SCIAMACHY measurements, Geophys. Res. Lett., 31, L24113, https://doi.org/10.1029/2004GL020994, 2004.

Ancellet, G., Daskalakis, N., Raut, J. C., Tarasick, D., Hair, J., Quennehen, B., Ravetta, F., Schlager, H., Weinheimer, A. J., Thompson, A. M., Johnson, B., Thomas, J. L., and Law, K. S.: Analysis of the latitudinal variability of tropospheric ozone in the Arctic using the large number of aircraft and ozonesonde observations in early summer 2008, Atmos. Chem. Phys., 16, 1334113358, https://doi.org/10.5194/acp-16-13341-2016, 2016.

Ayers, G. P., Gillett, R. W., Cainey, J. M., and Dick, A. L.: Chloride and bromide loss from sea-salt particles in Southern Ocean air, J. Atmos. Chem., 33, 299-319, 1999.

Banerjee, A., Archibald, A. T., Maycock, A. C., Telford, P., Abraham, N. L., Yang, X., Braesicke, P., and Pyle, J. A.: Lightning $\mathrm{NO}_{x}$, a key chemistry-climate interaction: impacts of future climate change and consequences for tropospheric oxidising capacity, Atmos. Chem. Phys., 14, 9871-9881, https://doi.org/10.5194/acp-14-9871-2014, 2014.

Barret, B., Williams, J. E., Bouarar, I., Yang, X., Josse, B., Law, K., Pham, M., Le Flochmoën, E., Liousse, C., Peuch, V. H., Carver, G. D., Pyle, J. A., Sauvage, B., van Velthoven, P., Schlager, H., Mari, C., and Cammas, J.-P.: Impact of West African Monsoon convective transport and lightning $\mathrm{NO}_{x}$ production upon the upper tropospheric composition: a multi-model study, Atmos. Chem. Phys., 10, 5719-5738, https://doi.org/10.5194/acp10-5719-2010, 2010.

Barrie, L. A., Bottenheim, J. W., Schnell, R. C., Crutzen, P. J., and Rasmussen, R. A.: Ozone destruction and photochemical reactions at polar sunrise in the lower Arctic atmosphere, Nature, 334, 138-141, https://doi.org/10.1038/334138a0, 1988.

Begoin, M., Richter, A., Weber, M., Kaleschke, L., Tian-Kunze, X., Stohl, A., Theys, N., and Burrows, J. P.: Satellite observations of long range transport of a large BrO plume in the Arctic, Atmos. Chem. Phys., 10, 6515-6526, https://doi.org/10.5194/acp10-6515-2010, 2010.

Blechschmidt, A.-M., Richter, A., Burrows, J. P., Kaleschke, L., Strong, K., Theys, N., Weber, M., Zhao, X., and Zien, A.: An exemplary case of a bromine explosion event linked to cyclone development in the Arctic, Atmos. Chem. Phys., 16, 1773-1788, https://doi.org/10.5194/acp-16-1773-2016, 2016.

Bottenheim, J. W. and Chan, E.: A trajectory study into the origin of spring time Arctic boundary layer ozone depletion, J. Geophys. Res.-Atmos., 111, D19301, https://doi.org/10.1029/2006JD007055, 2006.

Bottenheim, J. W., Gallant, A. G. and Brice, K. A.: Measurements of $\mathrm{NO}_{y}$ species and $\mathrm{O}_{3}$ at $82^{\circ} \mathrm{N}$ latitude, Geophys. Res. Lett., 13, 113-116, 1986.

Bottenheim, J. W., Fuentes J. D., Tarasick, D. W., and Anlauf, K. G.: Ozone in the Arctic lower troposphere during winter and spring 2000 (ALERT2000), Atmos. Environ., 36, 2535-2544, 2002.

Bottenheim, J. W., Netcheva, S., Morin, S., and Nghiem, S. V.: Ozone in the boundary layer air over the Arctic Ocean: measurements during the TARA transpolar drift 2006-2008, Atmos Chem. Phys., 9, 4545-4557, https://doi.org/10.5194/acp-9-45452009, 2009.

Braesicke, P., Keeble, J., Yang, X., Stiller, G., Kellmann, S., Abraham, N. L., Archibald, A., Telford, P., and Pyle, J. A.: Circulation anomalies in the Southern Hemisphere and ozone changes, Atmos. Chem. Phys., 13, 10677-10688, https://doi.org/10.5194/acp-13-10677-2013, 2013.

Breider, T., Chipperfield, M. P., Richards, N. A. D., Carslaw, K. S., Mann, G. W., and Spracklen, D. V.: The impact of BrO on dimethylsulfide in the remote marine boundary layer, Geophys. Res. Lett., 37, L02807, https://doi.org/10.1029/2009GL040868, 2009.

Buys, Z., Brough, N., Huey, L. G., Tanner, D. J., von Glasow, R., and Jones, A. E.: High temporal resolution $\mathrm{Br}_{2}, \mathrm{BrCl}$ and BrO observations in coastal Antarctica, Atmos. Chem. Phys., 13, 1329-1343, https://doi.org/10.5194/acp-13-1329-2013, 2013.

Callies, J., Corpaccioli, E., Eisinger, M., Hahne, A., and Lefebvre, A.: GOME-2 - Metop's Second-Generation Sensor for Operational Ozone Monitoring, ESA Bull.-Eur. Space, 102, 28-36, 2000.

Cao, L. and Gutheil, E.: Numerical simulation of tropospheric ozone depletion in the polar spring, Air Qual. Atmos. Health, 6, 673-686, https://doi.org/10.1007/s11869-013-0208-9, 2013.

Cao, L., Platt, U., and Gutheil, E.: Role of the boundary layer in the occurrence and termination of the tropospheric ozone depletion events in polar spring, Atmos. Environ., 132, 98-110, https://doi.org/10.1016/j.atmosenv.2016.02.034, 2016

Cavalieri, D. J. and Parkinson, C. L.: Arctic sea ice variability and trends, 1979-2010, The Cryosphere, 6, 881-889, https://doi.org/10.5194/tc-6-881-2012, 2012.

Choi, S., Wang, Y., Salawitch, R. J., Canty, T., Joiner, J., Zeng, T., Kurosu, T. P., Chance, K., Richter, A., Huey, L. G., Liao, J., Neuman, J. A., Nowak, J. B., Dibb, J. E., Weinheimer, A. J., Diskin, G., Ryerson, T. B., da Silva, A., Curry, J., Kinnison, D., Tilmes, S., and Levelt, P. F.: Analysis of satellite-derived Arctic tropospheric BrO columns in conjunction with aircraft measurements during ARCTAS and ARCPAC, Atmos. Chem. Phys., 12, 12551285, https://doi.org/10.5194/acp-12-1255-2012, 2012.

Choi, S., Theys, N., Salawitch, R. J., Wales, P. A., Joiner, J., Canty, T. P., Chance, K. Suleiman, R. M., Palm, S. P., Cullather, R. I., Darmenov, A. S., DaSilva, A., Kurosu, T. P., Hendrick, F., and Van Roozendael, M.: Link between arctic tropospheric BrO explosion observed from space and sea-salt aerosols from blowing snow investigated using ozone monitoring instrument $\mathrm{BrO}$ data and GEOS-5 data assimilation system, J. Geophys. Res.Atmos, 123, 6954-6983, https://doi.org/10.1029/2017JD026889, 2018. 
Cooper, O. R., Parrish, D. D., Ziemke, J., Balashov, N. V., Cupeiro, M., Galbally, I. E., Gilge, S., Horowitz, L., Jensen, N. R.,Lamarque, J.-F., Naik, V., Oltmans, S. J., Schwab, J., Shindell,D. T., Thompson, A. M., Thouret, V., Wang, Y., and Zbinden, R. M.: Global distribution and trends of tropospheric ozone:An observation-based review, Elementa, 2, 1-28, https://doi.org/10.12952/journal.elementa.000029, 2014.

Custard K. D., Raso, A. R. W., Shepson, P. B., Staebler, R. M., and Pratt, K. A.: Production and release of molecular bromine and chlorine from the Arctic coastal snowpack, ACS Earth and Space Chemistry, 1, 142-152, https://doi.org/10.1021/acsearthspacechem.7b00014, 2017.

de Caritat, P., Hall, G., G'1slason, S., Belsey, W., Braun, M., Goloubeva, N. I., Olsen, H. K., Scheie, J. O., and Vaive, J. E.: Chemical composition of arctic snow: concentration levels and regional distribution of major elements, Sci. Total Environ., 336, 183-199, https://doi.org/10.1016/j.scitotenv.2004.05.031, 2005.

Dee, D. P., Uppala, S. M., Simmons, A. J., Berrisford, P., Poli, P., Kobayashi, S., Andrae, U., Balmaseda, M. A., Balsamo, G., Bauer, P., Bechtold, P., Beljaars, A. C. M., van de Berg, L., Bidlot, J., Bormann, N., Delsol, C., Dragani, R., Fuentes, M., Geer, A. J., Haimberger, L., Healy, S. B., Hersbach, H., Hólm, E. V., Isaksen, L., Kållberg, P., Köhler, M., Matricardi, M., McNally, A. P., Monge-Sanz, B. M., Morcrette, J. J., Park, B. K., Peubey, C., de Rosnay, P., Tavolato, C., Thépaut, J. N., and Vitart, F.: The ERA-Interim reanalysis: configuration and performance of the data assimilation system, Q. J. Roy. Meteor. Soc., 137, 553-597, https://doi.org/10.1002/qj.828, 2011.

Dennison, F., Keeble, J., Morgenstern, O., Zeng, G., Abraham, N. L., and Yang, X.: Improvements to stratospheric chemistry scheme in the UM-UKCA (v10.7) model: solar cycle and heterogeneous reactions, Geosci. Model Dev., 12, 1227-1239, https://doi.org/10.5194/gmd-12-1227-2019, 2019.

Derwent, R. G., Parrish, D. D., Galbally, I. E., Stevenson, D. S., Doherty, R. M., Young, P. J., and Shallcross, D. E.: Interhemispheric differences in seasonal cycles of tropospheric ozone in the marine boundary layer: Observation - model comparisons, J. Geophys. Res.-Atmos., 121, 11075-11085, https://doi.org/10.1002/2016JD024836, 2016.

Emmons, L. K., Arnold, S. R., Monks, S. A., Huijnen, V., Tilmes, S., Law, K. S., Thomas, J. L., Raut, J.-C., Bouarar, I., Turquety, S., Long, Y., Duncan, B., Steenrod, S., Strode, S., Flemming, J., Mao, J., Langner, J., Thompson, A. M., Tarasick, D., Apel, E. C., Blake, D. R., Cohen, R. C., Dibb, J., Diskin, G. S., Fried, A., Hall, S. R., Huey, L. G., Weinheimer, A. J., Wisthaler, A., Mikoviny, T., Nowak, J., Peischl, J., Roberts, J. M., Ryerson, T., Warneke, C., and Helmig, D.: The POLARCAT Model Intercomparison Project (POLMIP): overview and evaluation with observations, Atmos. Chem. Phys., 15, 6721-6744, https://doi.org/10.5194/acp-15-6721-2015, 2015.

Engvall Stjernberg, A.-C., Skorokhod, A., Paris, J.D., Elansky, N., Nédélec, P., and Stohl, A.: Low concentrations of near-surface ozone in Siberia, Tellus, 63, 011607, https://doi.org/10.3402/tellusb.v64i0.11607, 2011.

Errera, Q., Daerden, F., Chabrillat, S., Lambert, J. C., Lahoz, W. A., Viscardy, S., Bonjean, S., and Fonteyn, D.: 4D-Var assimilation of MIPAS chemical observations: ozone and ni- trogen dioxide analyses, Atmos. Chem. Phys., 8, 6169-6187, https://doi.org/10.5194/acp-8-6169-2008, 2008.

Evans, M. J., Jacob, D. J., Atlas, E., Cantrell, C. A., Eisele, F., Flocke, F., Fried, A., Mauldin, R. L., Ridley, B. A., Wert, B., Talbot, R., Blake, D., Heikes, B., Snow, J., Walega, J., Weinheimer, A. J., and Dibb, J.: Coupled evolution of $\mathrm{BrO}_{x}-\mathrm{ClO}_{x}-\mathrm{HO}_{x}-\mathrm{NO}_{x}$ chemistry during bromine-catalyzed ozone depletion events in the arctic boundary layer, J. Geophys. Res.-Atmos., 108, 8368, https://doi.org/10.1029/2002JD002732, 2003.

Falk, S. and Sinnhuber, B.-M.: Polar boundary layer bromine explosion and ozone depletion events in the chemistryclimate model EMAC v2.52: implementation and evaluation of AirSnow algorithm, Geosci. Model Dev., 11, 1115-1131, https://doi.org/10.5194/gmd-11-1115-2018, 2018.

Fan, S. M. and Jacob, D. J.: Surface ozone depletion in Arctic spring sustained by bromine reactions on aerosols, Nature, 359, 522 524, 1992.

Feng, W., Chipperfield, M. P., Dhomse, S., Monge-Sanz, B. M., Yang, X., Zhang, K., and Ramonet, M.: Evaluation of cloud convection and tracer transport in a three-dimensional chemical transport model, Atmos. Chem. Phys., 11, 5783-5803, https://doi.org/10.5194/acp-11-5783-2011, 2011.

Fernandez, R. P., Carmona-Balea, A., Cuevas, C. A., Barrera, J. A., Kinnison, D. E., Lamarque, J.-F., BlaszczakBoxe, C., Kim, K., Choi, W., Hay, T., Blechschmidt, A. M., Schönhardt, A., Burrows, J. P., and Saiz-Lopez, A. Modeling the sources and chemistry of polar tropospheric halogens $(\mathrm{Cl}, \mathrm{Br}$, and I) using the CAM-Chem global chemistry-climate model, J. Adv. Model. Earth Sy., 11, 22592289, https://doi.org/10.1029/2019MS001655, 2019.

Frey, M. M., Norris, S. J., Brooks, I. M., Anderson, P. S., Nishimura, K., Yang, X., Jones, A. E., Nerentorp Mastromonaco, M. G., Jones, D. H., and Wolff, E. W.: First direct observation of sea salt aerosol production from blowing snow above sea ice, Atmos. Chem. Phys., 20, 2549-2578, https://doi.org/10.5194/acp20-2549-2020, 2020.

Frieß, U., Sihler, H., Sander, R., Pöhler, D., Yilmaz, S., and Platt, U.: The vertical distribution of $\mathrm{BrO}$ and aerosols in the Arctic: Measurements by active and passive differential optical absorption spectroscopy, J. Geophys. Res.-Atmos, 116, D00R04, https://doi.org/10.1029/2011JD015938, 2011.

Galbally, I. E., Schultz, M. G., Buchmann, B., Gilge, S., Guenther, F., Koide, H., Oltmans, S., Patrick, L., Scheel, H.-E., Smit, H., Steinbacher, M., Steinbrecht, W., Tarasova, O., Viallon, J., Volz-Thomas, A., Weber, M., Wielgosz R., and Zellweger C.: Guidelines for Continuous Measurement of Ozone in the Troposphere, GAW Report No 209, Publication WMONo. 1110, World Meteorological Organisation, Geneva Switzerland, 76 pp., available at: http://www.wmo.int/pages/prog/arep/ gaw/gaw-reports.html (last access: 3 December 2020), 2013.

Ganzeveld, L. and Lelieveld, J.: Dry deposition parametisation in a chemistry general circulation model and its influence on the distribution of reactive trace gases, J. Geophys. Res.-Atmos., 100, 20999-21012, https://doi.org/10.1029/95JD02266, 1995.

Gaudel, A. and Cooper, O. R.: Tropospheric Ozone Assessment Re-port: Present-day distribution and trends of tropospheric ozone relevant to climate and global atmospheric chemistry model evaluation, Elem. Sci. Anth., 6, 39, https://doi.org/10.1525/elementa.291, 2018. 
Giannakopoulos, C.: Modelling the impact of physical and removal processes on tropospheric chemistry, $\mathrm{PhD}$ thesis, University of Cambridge, UK, 1998.

Giannakopoulos, C., Good, P., Law, K. S., Wang, K.-Y., Akylas, E., and Koussis, A.: Rainfall parameterization in an offline chemical transport model, Atmos. Sci. Lett., 5, 82-88, https://doi.org/10.1002/asl.68, 2004.

Gregory, D. and Rowntree, P. R.: A mass flux convection scheme with representation of cloud ensemble characteristics and stability-dependent closure, Mon. Weather Rev., 118, 14831506, 1990.

Hatakka, J., Aalto, T., Aaltonen, V., Aurela, M., Hakola, H., Komppula, M., Laurela, T., Lihavainen, H., Paatero, J., Salminen, K., and Viisanen, Y.: Overview of the atmospheric research activities and results at Pallas GAW station, Boreal Environ. Res., 8, 365-383, 2003.

Hardacre, C., Wild, O., and Emberson, L.: An evaluation of ozone dry deposition in global scale chemistry climate models, Atmos. Chem. Phys., 15, 6419-6436, https://doi.org/10.5194/acp15-6419-2015, 2015.

Hauglustaine, D., Hourdin, F., Jourdain, L., Filliberti, M., Walters, S., Lamarque, J., and Holland, E.: Interactive chemistry in the Laboratoire de Météorolgie Dynamique general circulation model: Description and background tropospheric chemistry evaluation, J. Geophys. Res.-Atmos., 109, 4314, https://doi.org/10.1029/2003JD003957, 2004.

He, H., Tarasick, D. W., Hocking, W. K., Carey-Smith, T. K., Rochon, Y., Zhang, J., Makar, P. A., Osman, M., Brook, J., Moran, M. D., Jones, D. B. A., Mihele, C., Wei, J. C., Osterman, G., Argall, P. S., McConnell, J., and Bourqui, M. S.: Transport analysis of ozone enhancement in Southern Ontario during BAQS-Met, Atmos. Chem. Phys., 11, 2569-2583, https://doi.org/10.5194/acp-11-2569-2011, 2011.

Helmig, D., Oltmans, S. J., Carlson, D., Lamarque, J.-F., Jones, A., Labuschagne, C., Anlauf, K., and Hayden, K.: A Review of surface ozone in the polar regions, Atmos. Environ., 41, 5138-5161, 2007a.

Helmig, D., Oltmans, S. J., Morse, T. O., and Dibb, J. E.: What is causing high ozone at Summit, Greenland?, Atmos. Environ.,41, 5031-5043, https://doi.org/10.1016/j.atmosenv.2006.05.084, $2007 b$.

Holtslag, A. A. M. and Boville, B. A.: Local versus nonlocal boundary layer diffusion in a global climate model, J. Climate, 6, 1825-1842, https://doi.org/10.1175/15200442(1993)006<1825:LVNBLD>2.0.CO;2, 1993.

Hoyle, C. R., Marécal, V., Russo, M. R., Allen, G., Arteta, J., Chemel, C., Chipperfield, M. P., D’Amato, F., Dessens, O., Feng, W., Hamilton, J. F., Harris, N. R. P., Hosking, J. S., Lewis, A. C., Morgenstern, O., Peter, T., Pyle, J. A., Reddmann, T., Richards, N. A. D., Telford, P. J., Tian, W., Viciani, S., Volz-Thomas, A., Wild, O., Yang, X., and Zeng, G.: Representation of tropical deep convection in atmospheric models - Part 2: Tracer transport, Atmos. Chem. Phys., 11, 8103-8131, https://doi.org/10.5194/acp11-8103-2011, 2011.

Huang, J. and Jaeglé, L.: Wintertime enhancements of sea salt aerosol in polar regions consistent with a sea ice source from blowing snow, Atmos. Chem. Phys., 17, 3699-3712, https://doi.org/10.5194/acp-17-3699-2017, 2017.
Jacobi, H.-W., Morin, S., and Bottenheim, J. W.: Observation of widespread depletion of ozone in the springtime boundary layer of the central Arctic linked to mesoscale synoptic conditions, J. Geophys. Res.-Atmos., 115, D17302, https://doi.org/10.1029/2010JD013940, 2010.

Jaeglé, L., Quinn, P. K., Bates, T. S., Alexander, B., and Lin, J.-T.: Global distribution of sea salt aerosols: new constraints from in situ and remote sensing observations, Atmos. Chem. Phys., 11, 3137-3157, https://doi.org/10.5194/acp-11-3137-2011, 2011.

Jeuken, A., Siegmund, P., Heijboer, L., Feichter, J., and Bengtsson, L.: On the Potential of assimilating meteorological analyses in a global climate model for the purposes of model validation, J. Geophys. Res.-Atmos., 101, 939-16 950, 1996.

Johnson, C., Mann, G., Bellouin, N., Jacobi, H.-W., Morin, S., and Bottenheim, J. W.: Observation of widespread depletion of ozone in the springtime boundary layer of the central Arctic linked to mesoscale synoptic conditions, J. Geophys. Res.-Atmos., 115, D17302, https://doi.org/10.1029/2010JD013940, 2010.

Kaleschke, L., Richter, A., Burrows, J., Afe, O., Heygster, G., Notholt, J., Rankin, A. M., Roscoe, H. K., Hollwedel, J., Wagner, T., and Jacobi, H.-W.: Frost flowers on sea ice as a source of sea salt and their influence on tropospheric halogen chemistry, Geophys. Res. Lett., 31, L16114, https://doi.org/10.1029/2004GL020655, 2004.

Kerr, J. B., Fast, H., McElroy, C. T., Oltmans, S. J., Lathrop, J. A., Kyro E., Paukkunen, A., Claude, H., Köhler, U., Sreedharan, C. R., Takao, T., and Tsukagoshi, Y.: The 1991 WMO international ozonesonde intercomparison at Vanscoy, Canada, Atmos. Ocean, 32, 685-716, 1994.

Kirpes, R. M., Bonanno, D., May, N. W., Fraund, M., Barget, A. J., Moffet, R. C., and Pratt, K. A.: Wintertime Arctic sea spray aerosol composition controlled by sea ice lead microbiology, ACS Central Science, 5, 1760-1767, https://doi.org/10.1021/acscentsci.9b00541, 2019.

Komhyr, W. D.: Electrochemical concentration cells for gas analysis, Ann. Geophys., 25, 203-210, 1969.

Krnavek, L., Simpson, W. R., Carlson, D., Dominé, F., Douglas, T. A., and Sturm, M.: The chemical composition of surface snow in the Arctic: examining marine, terrestrial, and atmospheric influence, Atmos. Environ., 50, 349-359, https://doi.org/10.1016/j.atmosenv.2011.11.033, 2012.

Kwok, R. and Rothrock, D. A.: Decline in Arctic sea ice thickness from submarine and ICESat records: 1958-2008, Geophys. Res. Lett., 36, L15501, https://doi.org/10.1029/2009GL039035, 2009.

Laurila, T.: Observational study of transport and photochemical formation of ozone over northern Europe, J. Geophys. Res.-Atmos., 104, 26235-26243, 1999.

Law, K. S., Plantevin, P.-H., Shallcross, D. E., Rogers, H., Grouhel, C., Thouret, V., Marenco, A., and Pyle, J. A.: Evaluation of modelled $\mathrm{O}_{3}$ using MOZAIC data, J. Geophys. Res.-Atmos., 103, 721-740, 1998.

Law, K. S., Plantevin, P.-H., Thouret, V., Marenco, A., Asman, W. A. H., Lawrence, M., Crutzen, P. J., Müller, J.-F., Hauglustaine, D. A., and Kanakidou, M.: Comparison between global chemistry transport model results and Measurement of Ozone by Airbus In-ServiceAircraft (MOZAIC) data, J. Geophys. Res.Atmos., 105, 1503-1525, 2000.

Law, K. S. and Stohl A.: Arctic air pollution: Origins and impacts, Science, 315, 1537-1540, 2007. 
Laxon, S. W., Giles, K. A., Ridout, A. L., Wingham, D. J., Willatt, R., Cullen, R., Kwok, R., Schweiger, A., Zhang, J., Haas, C., Hendricks, S., Krishfield, R., Kurtz, N., Farrell, S., and Davidson, M.: CryoSat estimates of Arctic sea ice volume, Geophys. Res. Lett., 40, 732-737, https://doi.org/10.1002/grl.50193, 2013.

Legrand, M., Yang, X., Preunkert, S., and Theys, N.: Year-round records of sea salt, gaseous, and particulate inorganic brominein the atmospheric boundary layer at coastal (Dumont d'Urville) and central (Concordia) East Antarctic sites, J. Geophys. Res.Atmos., 121, 997-1023, https://doi.org/10.1002/2015JD024066, 2016.

Levine, J. G., Yang, X., Jones, A. E., and Wolff, E. W.: Sea salt as an ice core proxy for past sea ice extent: A processbased model study, J. Geophys. Res.-Atmos., 119, 5737-5756, https://doi.org/10.1002/2013JD020925, 2014.

Lewis, E. R. and Schwartz S. E.: Sea Salt Aerosol Production: Mechanisms, Methods, Measurements, and Models - A Critical Review, Geophysical Monograph Series, American Geophysical Union, Washington, 152, 413 pp., https://doi.org/10.1029/GM152, 2004.

Liao, J., Sihler, H., Huey, L. G., Neuman, J. A., Tanner, D. J., Frieß, U., Platt, U., Flocke, F. M., Orlando, J. J., Shepson, P. B., Beine,H. J., Weinheimer, A. J., Sjostedt, S. J., Nowak, J. B., Knapp, D. J., Staebler, R. M., Zheng, W., Sander, R., Hall, S. R., and Ullmann, K.: A comparison of Arctic $\mathrm{BrO}$ measurements by chemical ionization mass spectrometry and long path-differential optical absorption spectroscopy, J. Geophys. Res.-Atmos., 116, D00R02, https://doi.org/10.1029/2010JD014788, 2011.

Liao, J., Huey, L. G., Tanner, D. J., Flocke, F. M., Orlando,J. J., Neuman, J. A., Nowak, J. B., Weinheimer, A. J., Hall, S. R., Smith, J. N., Fried, A., Staebler, R. M., Wang, Y., Koo, J.-H., Cantrell, C. A., Weibring, P., Walega, J., Knapp, D. J., Shepson, P. B., and Stephens, C. R.: Observations of inorganic bromine $\left(\mathrm{HOBr}, \mathrm{BrO}\right.$, and $\left.\mathrm{Br}_{2}\right)$ speciation at Barrow, Alaska, in spring 2009, J. Geophys. Res.-Atmos., 117, D00R16, https://doi.org/10.1029/2011JD016641, 2012.

Lindsay, R. W. and J. Zhang: The thinning of Arctic sea ice, 19882003: Have we passed a tipping point?, J. Climate, 18, 48794894, 2005.

Liu, G., Liu, J., Tarasick, D. W., Fioletov, V. E., Jin, J. J., Moeini, O., Liu, X., Sioris, C. E., and Osman, M.: A global tropospheric ozone climatology from trajectory-mapped ozone soundings, Atmos. Chem. Phys., 13, 10659-10675, https://doi.org/10.5194/acp-13-10659-2013, 2013.

Lock, A. P., Brown, A. R., Bush, M. R., Martin, G. M., and Smith, R. N. B.: A new boundary-layer mixing scheme - 1. Scheme description and single-column model tests, Mon. Weather Rev., 128, 3187-3199, 2000.

Luhar, A. K., Woodhouse, M. T., and Galbally, I. E.: A revised global ozone dry deposition estimate based on a new two-layer parameterisation for air-sea exchange and the multi-year MACC composition reanalysis, Atmos. Chem. Phys., 18, 4329-4348, https://doi.org/10.5194/acp-18-4329-2018, 2018.

McClure-Begley, A., Morris, S., Salmi, T., Skov, H., Solberg, S., and Tarasick, D.: Ozone mixing ratio from 1974-01-01 to 201812-31 in Arctic locations (NCEI Accession 0220862), NOAA National Centers for Environmental Information, Dataset, available at: https://accession.nodc.noaa.gov/0220862, last access: 10 December 2020.
Michalowski, B. A., Francisco, J. S., Li, S. M., Barrie, L. A., Bottenheim, J. W., and Shepson, P. B.: A computer model study of multiphase chemistry in the Arctic boundary layer during polar sunrise, J. Geophys. Res.-Atmos., 105, 131-145, 2000.

Ming, A., Winton, V. H. L., Keeble, J., Abraham, N. L., Dalvi, M. C., Griffiths, P., Caillon, N., Jones, A .E., Mulvaney, R., Savarino, J., Frey, M. M., and Yang, X.: Stratospheric ozone changes from explosive tropical volcanoes: Modeling and ice core constraints, J. Geophys. Res.-Atmos., 125, e2019JD032290, https://doi.org/10.1029/2019JD032290, 2020.

Monks, P. S.: A review of the observations and origins of the spring ozone maximum, Atmos. Environ., 34, 3545-3561, https://doi.org/10.1016/S1352-2310(00)00129-1, 2000.

Monks, S. A., Arnold, S. R., Emmons, L. K., Law, K. S., Turquety, S., Duncan, B. N., Flemming, J., Huijnen, V., Tilmes, S., Langner, J., Mao, J., Long, Y., Thomas, J. L., Steenrod, S. D., Raut, J. C., Wilson, C., Chipperfield, M. P., Diskin, G. S., Weinheimer, A., Schlager, H., and Ancellet, G.: Multi-model study of chemical and physical controls on transport of anthropogenic and biomass burning pollution to the Arctic, Atmos. Chem. Phys., 15, 3575-3603, https://doi.org/10.5194/acp-15-3575-2015, 2015.

Morgenstern, O., Braesicke, P., O’Connor, F. M., Bushell, A. C., Johnson, C. E., Osprey, S. M., and Pyle, J. A.: Evaluation of the new UKCA climate-composition model Part 1: The stratosphere, Geosci. Model Dev., 2, 43-57, https://doi.org/10.5194/gmd-2-43-2009, 2009.

NOAA: HYSPLIT model outputs, available at: https://www.ready. noaa.gov/HYSPLIT.php, last access: 10 December 2020.

Olonscheck, D., Mauritsen, T., and Notz D.: Arctic sea-ice variability is primarily driven by atmospheric temperature fluctuations, Nat. Geosci., 12, 430-434, https://doi.org/10.1038/s41561-0190363-1, 2019.

Oltmans, S. J., Lefohn, A. S., Harris, J. M., Tarasick, D. W., Thompson, A. M., Wernli, H., Johnson, B. J., Novelli, P. C., Montzka, S. A., Ray, J. D., Patrick, L. C., Sweeney, C., Jefferson, A., Dann, T., Davies, J., Shapiro, M., and Holben. B. N.: Enhanced ozone over western North America from biomass burning in Eurasia during April 2008 as seen in surface and profile observations, Atmos. Environ., 44, 4497-4509, https://doi.org/10.1016/j.atmosenv.2010.07.004, 2010.

Parrella, J. P., Jacob, D. J., Liang, Q., Zhang, Y., Mickley, L. J., Miller, B., Evans, M. J., Yang, X., Pyle, J. A., Theys, N., and Van Roozendael, M.: Tropospheric bromine chemistry: implications for present and pre-industrial ozone and mercury, Atmos. Chem. Phys., 12, 6723-6740, https://doi.org/10.5194/acp12-6723-2012, 2012.

Parrish, D. D., Galbally, I. E., Lamarque, J. F., Naik, V., Horowitz, L., Shindell, D. T., Oltmans, S. J., Derwent, R., Tanimoto, H., Labuschagne, C., and Cupeiro, M.: Seasonal cycles of $\mathrm{O}_{3}$ in the marine boundary layer: Observation and model simulation comparisons, J. Geophys. Res.-Atmos., 121, 538-557, https://doi.org/10.1002/2015JD024101, 2016.

Platt, U.: Differential optical absorption spectroscopy (DOAS), in: Air Monitoring by Spectroscopic Techniques, Chem. Anal. Ser., edited by: Sigrist, M. W., John Wiley, New York, USA, 127, 2784, 1994.

Pöschl, U., von Kuhlmann, R., Poisson, N., and Crutzen, P.: Development and intercomparison of condensed isoprene oxidation 
mechanisms for global atmospheric modelling, J. Atmos. Chem., 37, 29-52, 2000.

Pratt, K. A., Custard, K. D., Shepson, P. B., Douglas, T. A., Pöhler, D., General, S., Zielcke, J., Simpson, W. R., Platt, U., Tanner, D. J., Huey, L. G., Carlsen, M., and Stirm, B. H.: Photochemical production of molecular bromine in Arctic surface snowpacks, Nat. Geosci., 6, 351-356, https://doi.org/10.1038/NGEO1779, 2013.

Quinn, P. K., Bates, T. S., Baum, E., Doubleday, N., Fiore, A. M., Flanner, M., Fridlind, A., Garrett, T. J., Koch, D., Menon, S., Shindell, D., Stohl, A., and Warren, S. G.: Shortlived pollutants in the Arctic: their climate impact and possible mitigation strategies, Atmos. Chem. Phys., 8, 1723-1735, https://doi.org/10.5194/acp-8-1723-2008, 2008.

Rayner, N. A., Parker, D. E., Horton, E. B., Folland, C. K., Alexander, L. V., Rowell, D. P., Kent, E. C., and Kaplan, A.: Global analyses of sea surface temperature, sea ice, and night marine air temperature since the late nineteenth century, J. Geophys. Res.-Atmos., 108, 4407, https://doi.org/10.1029/2002JD002670, 2003.

Reader, M. C. and McFarlane, N.: Sea-salt aerosol distribution during the Last Glacial Maximum and its implications for mineral dust, J. Geophys. Res.-Atmos., 108, 4253, https://doi.org/10.1029/2002JD002063, 2003.

Rhodes, R. H., Yang, X., Wolff, E. W., McConnell, J. R., and Frey, M. M.: Sea ice as a source of sea salt aerosol to Greenland ice cores: a model-based study, Atmos. Chem. Phys., 17, 94179433, https://doi.org/10.5194/acp-17-9417-2017, 2017.

Rolph, G., Stein, A., and Stunder, B.: Real-time Environmental Applications and Display sYstem: READY, Environ. Modell. Softw., 95, 210-228, https://doi.org/10.1016/j.envsoft.2017.06.025, 2017.

Russo, M. R., Marécal, V., Hoyle, C. R., Arteta, J., Chemel, C., Chipperfield, M. P., Dessens, O., Feng, W., Hosking, J. S., Telford, P. J., Wild, O., Yang, X., and Pyle, J. A.: Representation of tropical deep convection in atmospheric models - Part 1: Meteorology and comparison with satellite observations, Atmos. Chem. Phys., 11, 2765-2786, https://doi.org/10.5194/acp11-2765-2011, 2011.

Saiz-Lopez, A., Plane, J. M. C., Mahajan, A. S., Anderson, P. S., Bauguitte, S. J.-B., Jones, A. E., Roscoe, H. K., Salmon, R. A., Bloss, W. J., Lee, J. D., and Heard, D. E.: On the vertical distribution of boundary layer halogens over coastal Antarctica: implications for $\mathrm{O}_{3}, \mathrm{HO}_{x}, \mathrm{NO}_{x}$ and the $\mathrm{Hg}$ lifetime, Atmos. Chem. Phys., 8, 887-900, https://doi.org/10.5194/acp-8887-2008, 2008.

Salawitch, R., Canty, T., Kurosu, T., Chance, K., Liang, Q., daSilva, A., Pawson, S., Nielsen, J. E., Rodriguez, J. M., Bhartia, P. K., Liu, X., Huey, L. G., Liao, J., Stickel, R. E., Tanner, D.J., Dibb, J. E., Simpson, W. R., Donohoue, D., Weinheimer, A.,Flocke, F., Knapp, D., Montzka, D., Neuman, J. A., Nowak, J. B., Ryerson, T. B., Oltmans, S., Blake, D. R., Atlas, E. L., Kinnison, D. E., Tilmes, S., Pan, L. L., Hendrick, F., Van Roozendael, M., Kreher, K., Johnston, P. V., Gao, R. S., Johnson, B., Bui, T. P., Chen, G., Pierce, R. B., Crawford, J. H., and Jacob, D. J.: A new interpretation of total column BrO during Arctic spring, Geophys. Res. Lett., 37, L21805, https://doi.org/10.1029/2010GL043798, 2010.
Sander, R., Keene, W. C., Pszenny, A. A. P., Arimoto, R., Ayers, G. P., Baboukas, E., Cainey, J. M., Crutzen, P. J., Duce, R. A., Hönninger, G., Huebert, B. J., Maenhaut, W., Mihalopoulos, N., Turekian, V. C., and Van Dingenen, R.: Inorganic bromine in the marine boundary layer: a critical review, Atmos. Chem. Phys., 3, 1301-1336, https://doi.org/10.5194/acp-3-1301-2003, 2003.

Savage, N. H., Law, K. S., Pyle, J. A., Richter, A., Nüß, H., and Burrows, J. P.: Using GOME $\mathrm{NO}_{2}$ satellite data to examine regional differences in TOMCAT model performance, Atmos. Chem. Phys., 4, 1895-1912, https://doi.org/10.5194/acp-4-18952004, 2004.

Schmidt, G., Ruedy, R., Hansen, J., Aleinov, I., Bell, N., Bauer, M., Bauer, S., Cairns, B., Canuto, V., Cheng, Y., Del Genio, A., Faluvegi, G., Friend, A., Hall, T., Hu, Y., Kelley, M., Kiang, N., Koch, D., Lacis, A., Lerner, J., Lo, K., Miller, R., Nazarenko, L., Oinas, V., Perlwitz, J., Perlwitz, J., Rind, D., Romanou, A., Russell, G., Sato, M., Shindell, D., Stone, P., Sun, S., Tausnev, N., Thresher, D., and Yao, M.-S.: Present day atmospheric simulations using GISS ModelE: Comparison to in-situ, satellite and reanalysis data, J. Climate, 19, 153-192, 2006.

Schultz, M. G., Schröder, S., Lyapina, O., Cooper, O., Galbally, I., Petropavlovskikh, I., von Schneidemesser, E., Tanimoto, H., Elshorbany, Y., Naja, M., Seguel, R., Dauert, U., Eckhardt, P., Feigenspahn, S., Fiebig, M., Hjellbrekke, A.-G., Hong, Y.-D., Christian Kjeld, P., Koide, H., Lear, G., Tarasick, D., Ueno, M., Wallasch, M., Baumgardner, D., Chuang, M.-T., Gillett, R., Lee, M., Molloy, S., Moolla, R., Wang, T., Sharps, K., Adame, J. A., Ancellet, G., Apadula, F., Artaxo, P., Barlasina, M., Bogucka, M., Bonasoni, P., Chang, L., Colomb, A., Cuevas, E., Cupeiro, M., Degorska, A., Ding, A., Fröhlich, M., Frolova, M., Gadhavi, H., Gheusi, F., Gilge, S., Gonzalez, M. Y., Gros, V., Hamad, S. H., Helmig, D., Henriques, D., Hermansen, O., Holla, R., Huber, J., Im, U., Jaffe, D. A., Komala, N., Kubistin, D., Lam, K.-S., Laurila, T., Lee, H., Levy, I., Mazzoleni, C., Mazzoleni, L., McClure-Begley, A., Mohamad, M., Murovic, M., NavarroComas, M., Nicodim, F., Parrish, D., Read, K. A., Reid, N., Ries, L., Saxena, P., Schwab, J. J., Scorgie, Y., Senik, I., Simmonds, P., Sinha, V., Skorokhod, A., Spain, G., Spangl, W., Spoor, R., Springston, S. R., Steer, K., Steinbacher, M., Suharguniyawan, E., Torre, P., Trickl, T., Weili, L., Weller, R., Xu, X., Xue, L., and Zhiqiang, M., Tropospheric Ozone Assessment Report: Database and Metrics Data of Global Surface Ozone Observations, Elem. Sci. Anth., 5, 26 pp., https://doi.org/10.1525/elementa.244, 2017.

Seabrook, J. A., Whiteway, J. A., Gray, L. H., Staebler, R., and Herber, A.: Airborne lidar measurements of surface ozone depletion over Arctic sea ice, Atmos. Chem. Phys., 13, 6023-6029, https://doi.org/10.5194/acp-13-6023-2013, 2013.

Shindell, D. T., Chin, M., Dentener, F., Doherty, R. M., Faluvegi, G., Fiore, A. M., Hess, P., Koch, D. M., MacKenzie, I. A., Sanderson, M. G., Schultz, M. G., Schulz, M., Stevenson, D. S., Teich, H., Textor, C., Wild, O., Bergmann, D. J., Bey, I., Bian, H., Cuvelier, C., Duncan, B. N., Folberth, G., Horowitz, L. W., Jonson, J., Kaminski, J. W., Marmer, E., Park, R., Pringle, K. J., Schroeder, S., Szopa, S., Takemura, T., Zeng, G., Keating, T. J., and Zuber, A.: A multi-model assessment of pollution transport to the Arctic, Atmos. Chem. Phys., 8, 5353-5372, https://doi.org/10.5194/acp-8-5353-2008, 2008.

Simpson, W. R., von Glasow, R., Riedel, K., Anderson, P., Ariya, P., Bottenheim, J., Burrows, J., Carpenter, L. J., Frieß, U., Good- 
site, M. E., Heard, D., Hutterli, M., Jacobi, H.-W., Kaleschke, L., Neff, B., Plane, J., Platt, U., Richter, A., Roscoe, H., Sander, R., Shepson, P., Sodeau, J., Steffen, A., Wagner, T., and Wolff, E.: Halogens and their role in polar boundary-layer ozone depletion, Atmos. Chem. Phys., 7, 4375-4418, https://doi.org/10.5194/acp7-4375-2007, 2007a.

Simpson, W. R., Carlson, D., Hönninger, G., Douglas, T. A., Sturm, M., Perovich, D., and Platt, U.: First-year sea-ice contact predicts bromine monoxide $(\mathrm{BrO})$ levels at Barrow, Alaska better than potential frost flower contact, Atmos. Chem. Phys., 7, 621-627, https://doi.org/10.5194/acp-7-621-2007, 2007b.

Skov, H., Christensen, J., Goodsite, M. E., Heidam, N. Z., Jensen, B., Wåhlin, P., and Geernaert, G.: The fate of elemental mercury in Arctic during atmospheric mercury depletion episodes and the load of atmospheric mercury to Arctic, Environ. Sci. Technol., 38, 2373-2382, 2004.

Skov, H., Hjorth, J., Nordstrøm, C., Jensen, B., Christoffersen, C., Bech Poulsen, M., Baldtzer Liisberg, J., Beddows, D., Dall'Osto, M., and Christensen, J. H.: Variability in gaseous elemental mercury at Villum Research Station, Station Nord, in North Greenland from 1999 to 2017, Atmos. Chem. Phys., 20, 13253-13265, https://doi.org/10.5194/acp-20-13253-2020, 2020.

Smit, H. G. J. and Kley, D.: JOSIE: The 1996 WMO International intercomparison of ozonesondes under quasi flight conditions in the environmental simulation chamber at Jülich, WMO Global Atmosphere Watch Report No. 130, WMO TD No. 926, World Meteorological Organization, Geneva, Switzerland, 108 pp., 1998.

Smit, H. G. J., Straeter, W., Johnson, B., Oltmans, S., Davies, J., Tarasick, D. W., Hoegger, B., Stubi, R., Schmidlin, F., Northam, T., Thompson, A., Witte, J., Boyd, I., and Posny, F.: Assessment of the performance of ECC-ozonesondes under quasi-flight conditions in the environmental simulation chamber: Insights from the Juelich Ozone Sonde Intercomparison Experiment (JOSIE), J. Geophys Res.-Atmos., 112, D19306, https://doi.org/10.1029/2006JD007308, 2007.

Stein, A. F., Draxler, R. R, Rolph, G. D., Stunder, B. J. B., Cohen, M. D., and Ngan, F.: NOAA's HYSPLIT atmospheric transport and dispersion modeling system, B. Am. Meteorol. Soc., 96, 2059-2077, https://doi.org/10.1175/BAMS-D-14$00110.1,2015$.

Tang, T. and McConnell, J. C.: Autocatalytic release of bromine from Arctic snow pack during polar sunrise, Geophys. Res. Lett., 23, 2633-2636, 1996.

Tarasick, D. W. and Bottenheim, J. W.: Surface ozone depletion episodes in the Arctic and Antarctic from historical ozonesonde records, Atmos. Chem. Phys., 2, 197-205, https://doi.org/10.5194/acp-2-197-2002, 2002.

Tarasick, D. W., Davies, J., Smit, H. G. J., and Oltmans, S. J.: A re-evaluated Canadian ozonesonde record: measurements of the vertical distribution of ozone over Canada from 1966 to 2013, Atmos. Meas. Tech., 9, 195-214, https://doi.org/10.5194/amt-9195-2016, 2016.

Tarasick, D., Galbally, I. E., Cooper, O. R., Schultz, M. G., Ancellet, G., Leblanc, T., Wallington, T. J., Ziemke, J., Liu, X., Steinbacher, M., Staehelin, J., Vigouroux, C., Hannigan, J. W., García, O., Foret, G., Zanis, P., Weatherhead, E., Petropavlovskikh, I., Worden, H., Osman, M., Liu, J., Chang, K.-L., Gaudel, A., Lin, M., Granados-Muñoz, M., Thompson, A. M., Olt- mans, S. J., Cuesta, J., Dufour, G., Thouret, V., Hassler, B., Trickl, T., and Neu, J. L.: Tropospheric Ozone Assessment Report: Tropospheric ozone from 1877 to 2016, observed levels, trends and uncertainties, Elem. Sci. Anth., 7, 39, https://doi.org/10.1525/elementa.376, 2019a.

Tarasick, D. W., Carey-Smith, T. K., Hocking, W. K., Moeini, O., He, H., Liu, J., Osman, M., Thompson, A. M., Johnson, B., Oltmans, S. J., and Merrill, J. T.: Quantifying stratospheretroposphere transport of ozone using balloon-borne ozonesondes, radar windprofilers and trajectory models, Atmos. Environ., 198, 496-509, https://doi.org/10.1016/j.atmosenv.2018.10.040, $2019 b$.

Tarasick, D. W., Smit, H. G. J., Thompson, A. M., Morris, G. A., Witte, J. C., Davies, J., Nakano, T., van Malderen, R., Stauffer, R. M., Deshler, T., Johnson, B. J., Stübi, R., Oltmans, S. J., and Vömel, H.: Improving ECC Ozonesonde Data Quality: Assessment of Current Methods and Outstanding Issues, Earth Space Sci., accepted 2020.

Telford, P. J., Braesicke, P., Morgenstern, O., and Pyle, J. A.: Technical Note: Description and assessment of a nudged version of the new dynamics Unified Model, Atmos. Chem. Phys., 8, 17011712, https://doi.org/10.5194/acp-8-1701-2008, 2008.

Theys, N., Van Roozendael, M., Hendrick, F., Yang, X., De Smedt, I., Richter, A., Begoin, M., Errera, Q., Johnston, P. V., Kreher, K., and De Mazière, M.: Global observations of tropospheric BrO columns using GOME-2 satellite data, Atmos. Chem. Phys., 11, 1791-1811, https://doi.org/10.5194/acp-11-1791-2011, 2011.

Thomas, J. L., Stutz, J., Lefer, B., Huey, L. G., Toyota, K., Dibb, J. E., and von Glasow, R.: Modeling chemistry in and above snow at Summit, Greenland - Part 1: Model description and results, Atmos. Chem. Phys., 11, 4899-4914, https://doi.org/10.5194/acp11-4899-2011, 2011.

Tiedtke, M.: A comprehensive mass flux scheme for cumulus parameterization in large scale models, Mon. Weather Rev., 117, 1779-1800, https://doi.org/10.1175/15200493(1989)117<1779:ACMFSF>2.0.CO;2, 1989.

Toyota, K., McConnell, J. C., Lupu, A., Neary, L., McLinden, C. A., Richter, A., Kwok, R., Semeniuk, K., Kaminski, J. W., Gong, S.-L., Jarosz, J., Chipperfield, M. P., and Sioris, C. E.: Analysis of reactive bromine production and ozone depletion in the Arctic boundary layer using 3-D simulations with GEM-AQ: inference from synoptic-scale patterns, Atmos. Chem. Phys., 11, 3949-3979, https://doi.org/10.5194/acp-11-3949-2011, 2011.

Uttal, T., Starkweather, S., Drummond, J. R., Vihma, T., Makshtas, A. P., Darby, L. S., Burkhart, J. F., Cox, C. J., Schmeisser, L. N., Haiden, T., Maturilli, M., Shupe, M. D., De Boer, G., Saha, A., Grachev, A. A., Crepinsek, S. M., Bruhwiler, L., Goodison, B., McArthur, B., Walden, V. P., Dlugokencky, E. J., Persson, P. O. G., Lesins, G., Laurila, T., Ogren, J. A., Stone, R., Long, C. N., Sharma, S., Massling, A., Turner, D. D., Stanitski, D. M., Asmi, E., Aurela, M., Skov, H., Eleftheriadis, K., Virkkula, A., Platt, A., Forland, E. J., Iijima, Y., Nielsen, I. E., Bergin, M. H., Candlish, L., Zimov, N. S., Zimov, S. A., O’Neill, N. T., Fogal, P. F., Kivi, R., Konopleva-Akish, E. A., Verlinde, J., Kustov, V. Y., Vasel, B., Ivakhov, V. M., Viisanen, Y., and Intrieri, J. M.: International Arctic Systems for Observing the Atmosphere: An International Polar Year Legacy Consortium, B. Am. Meteorol. Soc., 97, 1033-1056, 2016. 
Viscardy, S., Errera, Q., Christophe, Y., Chabrillat, S., and Lambert, J.-C.: Evaluation of Ozone Analyses From UARS MLS Assimilation by BASCOE Between 1992 and 1997, IEEE J-STARS, 3, 190-202, https://doi.org/10.1109/JSTARS.2010.2040463, 2010.

Vogt, R., Crutzen, P. J., and Sander, R.: A mechanism for halogen release from sea-salt aerosol in the remote marine boundary layer, Nature, 383, 327-330, https://doi.org/10.1038/383327a0, 1996.

Voulgarakis, A., Yang, X., and Pyle, J. A.: How different would tropospheric oxidation be over an ice-free Arctic?, Geophys. Res. Lett., 36, L23807, https://doi.org/10.1029/2009GL040541, 2009a.

Voulgarakis, A., Wild, O., Savage, N. H., Carver, G. D., and Pyle, J. A.: Clouds, photolysis and regional tropospheric ozone budgets, Atmos. Chem. Phys., 9, 8235-8246, https://doi.org/10.5194/acp9-8235-2009, 2009b.

Wagner, T., and Platt, U.: Satellite mapping of enhanced BrO concentrations in the troposphere, Nature, 395, 486-490, 1998.

Walker T. W., Jones, D. B. A., Parrington, M., Henze, D. K., Murray, L. T., Bottenheim, J. W., Anlauf, K., Worden, J. R., Bowman, K. W., Shim, C., Singh, K., Kopacz, M., Tarasick, D. W., Davies, J., von der Gathen, P., Thompson, A. M., and Carouge, C. C.: Impacts of midlatitude precursor emissions and local photochemistry on ozone abundances in the Arctic, J. Geophys. Res.Atmos., 117, D01305, https://doi.org/10.1029/2011JD016370, 2012.

Wang, K. Y., Pyle, J. A., Sandersen, M. G., and Bridgeman, C.: Implimentation of a convective atmospheric boundary layer scheme in a tropospheric chemistry transport model, J. Geophys. Res.Atmos., 104, 729-745, 1999.

Wang, S., McNamara, S. M., Moore, C. W., Obrist, D., Steffen, A., Shepson, P. B., Staebler, R. M., Raso, A. R. W., and Pratt, K. A.: Direct detection of atmospheric atomic bromine leading to mercury and ozone depletion, P. Natl. Acad. Sci. USA, 116, 1447914484, https://doi.org/10.1073/pnas.1900613116, 2019.

Warwick, N. J., Pyle, J. A., Carver, G. D., Yang, X., Savage, N. H., O'Connor, F. M., and Cox, R. A.: Global modeling of biogenic bromocarbons, J. Geophys. Res.-Atmos., 111, D24305, https://doi.org/10.1029/2006JD007264, 2006.

Yang, X., Cox, R. A., Warwick, N. J., Pyle, J. A., Carver, G. D., O'Connor, F. M., and Savage, N. H.: Tropospheric bromine chemistry and its impacts on ozone: A model study, J. Geophys. Res.-Atmos., 110, D23311, https://doi.org/10.1029/2005JD006244, 2005.
Yang, X., Pyle, J. A., and Cox, R. A.: Sea salt aerosol production and bromine release: Role of snow on sea ice, Geophys. Res. Lett., 35, L16815, https://doi.org/10.1029/2008gl034536, 2008.

Yang, X., Pyle, J. A., Cox, R. A., Theys, N., and Van Roozendael, M.: Snow-sourced bromine and its implications for polar tropospheric ozone, Atmos. Chem. Phys., 10, 7763-7773, https://doi.org/10.5194/acp-10-7763-2010, 2010.

Yang, X., Abraham, N. L., Archibald, A. T., Braesicke, P., Keeble, J., Telford, P. J., Warwick, N. J., and Pyle, J. A.: How sensitive is the recovery of stratospheric ozone to changes in concentrations of very short-lived bromocarbons?, Atmos. Chem. Phys., 14, 10431-10438, https://doi.org/10.5194/acp-14-104312014, 2014.

Yang, X., Frey, M. M., Rhodes, R. H., Norris, S. J., Brooks, I. M., Anderson, P. S., Nishimura, K., Jones, A. E., and Wolff, E. W.: Sea salt aerosol production via sublimating wind-blown saline snow particles over sea ice: parameterizations and relevant microphysical mechanisms, Atmos. Chem. Phys., 19, 8407-8424, https://doi.org/10.5194/acp-19-8407-2019, 2019.

Young, P. J., Arneth, A., Schurgers, G., Zeng, G., and Pyle, J. A.: The $\mathrm{CO}_{2}$ inhibition of terrestrial isoprene emission significantly affects future ozone projections, Atmos. Chem. Phys., 9, 2793 2803, https://doi.org/10.5194/acp-9-2793-2009, 2009.

Young, P. J., Naik, V., Fiore, A. M., Gaudel, A., Guo, J., Lin, M. Y., Neu, J., Parrish, D., Reider, H. E., Schnell, J. L., Tilmes, S., Wild, O., Zhang, L., Brandt, J., Delcloo, A., Doherty, R. M., Geels, C., Hegglin, M., Hu., L., Im, U., Kumar, R., Luhar, A., Murray, L., Plummer, D., Rodriguez, J., Saiz-Lopez, A., Schultz, M. G., Woodhouse, M., Zeng, G., and Ziemke, J., Tropospheric Ozone Assessment Report: Assessment of global-scale model performance for global and regional ozone distributions, variability, and trends, Elem. Sci. Anth., 6, 10, https://doi.org/10.1525/elementa.265, 2018.

Zhao, X., Strong, K., Adams, C., Schofield, R., Yang, X., Richter, A., Friess, U., Blechschmidt, A.-M., and Koo, J.-H.: A case study of a transported bromine explosion event in the Canadian high arctic, J. Geophys. Res.-Atmos., 121, 457-477, https://doi.org/10.1002/2015JD023711, 2016.

Zhao, X., Weaver, D., Bognar, K., Manney, G., Millán, L., Yang, X., Eloranta, E., Schneider, M., and Strong, K.: Cyclone-induced surface ozone and HDO depletion in the Arctic, Atmos. Chem. Phys., 17, 14955-14974, https://doi.org/10.5194/acp-17-149552017, 2017. 